\title{
Four Gd(III) complexes appended to a porphyrin: a water-soluble molecular theranostic agent with remarkable relaxivity suited for MRI tracking of the photosensitizer
}

Angélique Sour, ${ }^{\text {[a] }}$ Sébastien Jenni, ${ }^{\text {[a] }}$, Ana Ortí-Suárez, ${ }^{\text {[a] }}$ Julie Schmitt, ${ }^{\text {[a] }}$ Valérie Heitz, ${ }^{[a]^{*}}$ Frédéric Bolze, ${ }^{[b]}$ Paulo Loureiro de Sousa, ${ }^{[c]}$ Chrystelle Po, ${ }^{[c]}$ Célia S. Bonnet, ${ }^{[0]}$ Agnès Pallier, ${ }^{[0]}$ Éva Tóth, ${ }^{(\mathrm{dut})}$ and Barbara Ventura ${ }^{(\mathrm{ec|})}$

[a] Laboratoire de Synthèse des Assemblages Moléculaires Multifonctionnels, Institut de Chimie de Strasbourg, CNRS/UMR 7177, Université de Strasbourg, 4, rue Blaise Pascal, 67000 Strasbourg (France).E-mail: v.heitz@unistra.fr

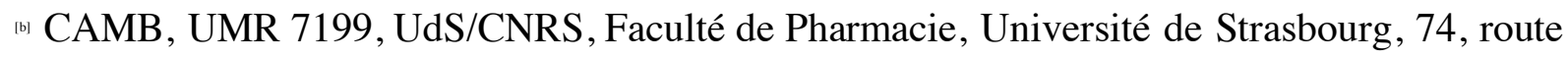
du Rhin, 67401 Illkirch (France). E-mail: frederic.bolze@unistra.fr

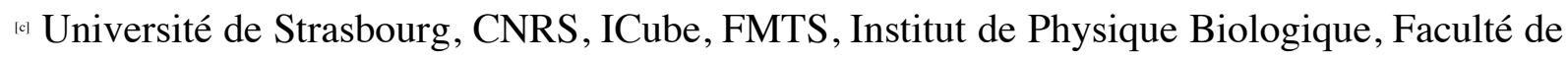
Médecine 4, rue Kirschleger, 67085 Strasbourg Cedex. E-mail : ploureiro@unistra.fr

${ }^{\left[{ }^{\circledR}\right.}$ Centre de Biophysique Moléculaire CNRS UPR4301, Université d'Orléans, rue Charles Sadron, CS 80054, 45071 Orléans Cedex 2, (France).E-mail: eva.jakabtoth@cnrs.fr

(e) Istituto ISOF-CNR, Via P. Gobetti 101, 40129 Bologna (Italy). E-mail: barbara.ventura@isof.cnr.it

\begin{abstract}
A molecular theranostic agent for magnetic resonance imaging (MRI) and photodynamic therapy (PDT) consisting of four [GdDTTA] complexes (DTTA: diethylenetriamine-N, N, N", N"- tetraacetate) linked to a meso-tetraphenylporphyrin core, as well as its Y(III) analogue, were synthesized. A variety of physicochemical methods were used to characterize the Gd(III)-conjugate 1 both as an MRI contrast agent and as a photosensitizer. The proton relaxivity measured in water at $20 \mathrm{MHz}$ and $25^{\circ} \mathrm{C}, r_{1}=43.7 \mathrm{mmol}^{-1} \cdot \mathrm{s}^{-1}$ per $\mathrm{Gd}$ center, is the highest reported for a bishydrated Gd(III)-based contrast agent of medium size and can be related to the rigidity of the molecule. The complex displays also a remarkable singlet oxygen quantum yield of $\phi_{\Delta}=0.45$ in water, similar to that of a meso-tetrakis-sulfonated porphyrin. We also evidenced the ability of the Gd(III) conjugate to penetrate in cancer cells with low cytotoxicity. Its phototoxicity on Hela cells was evaluated following incubation at low
\end{abstract}


micromolar concentration and moderate light irradiation $\left(21 \mathrm{~J} / \mathrm{cm}^{2}\right)$ induced $50 \%$ of cell death. Altogether, these results demonstrate the high potential of this conjugate as a theranostic agent for MRI and PDT.

\section{Introduction}

Theranostics aims to combine imaging and therapy to monitor drug delivery, drug release and treatment efficiency. ${ }^{1}$ This can be achieved with the association of diagnostic and therapeutic agents within the same molecular or nanoparticle system allowing identical biodistribution of these components. Today, most of the theranostic agents are based on nanosized platforms, such as various types of nanoparticles, ${ }^{2-4}$ polymeric conjugates, ${ }^{5-7}$ liposomes and micelles. ${ }^{8-11}$ In contrast to nanosized platforms, the advantages of molecular water-soluble agents involve easier evaluation and control of the physicochemical properties, which make them appropriate for theranostic applications. ${ }^{12-14}$

In the panoply of imaging modalities, MRI has become one of the most important tools, both in clinical practice and biomedical research. It is noninvasive and enables threedimension imaging of soft tissues with excellent spatial and temporal resolution. The contrast in MRI mainly depends on the relaxation times of water protons and on the proton density in the different tissues. Contrast agents are commonly used to enhance the relaxation of interacting water protons and thus to improve image contrast. ${ }^{15-19}$ The efficiency of a contrast agent, measured by its relaxivity $\left(r_{1}\right)$, is defined as the paramagnetic enhancement of the water proton longitudinal relaxation rate referred to one millimolar concentration of the contrast agent. Current clinical contrast agents are small polar $\mathrm{Gd}(\mathrm{III})$ complexes of DOTA-type macrocycles $\left(\mathrm{H}_{4}\right.$ DOTA $=$ 1,4,7,10-tetraazacyclododecane- $\mathrm{N}, \mathrm{N},{ }^{\prime},{ }^{\prime},{ }^{\prime},{ }^{\prime},{ }^{\prime}-1,4,7,10$-tetraacetic acid) or DTPA-based chelates $\left(\mathrm{H}_{5} \mathrm{DTPA}=\right.$ diethylenetriamine pentaacetic acid $)$ with modest relaxivities of $\sim 4-5 \mathrm{mM}^{-1} . \mathrm{S}^{-1}$ at clinical magnetic fields $(1-3 \mathrm{~T})$. Low sensitivity remains a major drawback of MRI requiring administration of high doses of the contrast agent (0.025 $0.3 \mathrm{mmol} / \mathrm{kg}){ }_{.}^{20} \mathrm{As}$ a result, there is a continuous interest in the development of more efficient contrast agents. Two main approaches have been considered to increase the molecular relaxivity: optimizing the molecular parameters that govern relaxivity and gathering several gadolinium complexes within a single molecular entity. Relaxivity is mainly related to three microscopic parameters of the Gd(III) complex, (i) the molecular rotational correlation time $\left(\tau_{\mathrm{R}}\right)$, (ii) the number of inner-sphere water molecules $(q)$ and (iii) the water exchange rate of these water molecules $\left(k_{\mathrm{c} x}\right)$. Considerable effort has been devoted to optimize these factors for 
Gd(III)-based contrast agents. The molecular tumbling was slowed down with medium-sized or macromolecular architectures which resulted in a remarkable relaxivity improvement at intermediate magnetic fields $\left(0.5\right.$ - 3T) as compared to commercial agents. ${ }^{21}$ Also, the use of bishydrated instead of the classical monohydrated Gd(III) complexes was shown to almost double the relaxivity at all magnetic fields..$^{2230}$

Molecular systems combining porphyrin or related structures and Gd(III) complexes have been investigated as targeted MRI probes, bimodal agents for magnetic and fluorescence imaging or to improve relaxivity by increasing the molecular size. ${ }^{31-35}$ In particular, gadophrin-2, composed of two [GdDTPA] $]^{2-}$ complexes linked to a porphyrin core, was extensively studied and found to be necrosis-avid. ${ }^{31}$ Free-base and $\mathrm{Cu}$ (II) porphyrins linked to 1, 2 or 4 [GdDO3A-amide] complexes were developed as bimodal MRI/PET or MRI/optical imaging agents and have shown improved relaxivities. ${ }^{32,33}$ Significant contrast enhancement was observed both in vitro and in vivo for a $\mathrm{Cu}$ (II) porphyrazine linked to two [GdDO3Aamide] complexes as compared to the monomeric [GdDOTA $]^{-} .^{34}$

Photodynamic therapy (PDT) is a minimally invasive and localized medical treatment used in oncology, ophthalmology and dermatology. ${ }^{36,} 37$ PDT requires a photosensitizer which, after light excitation, is able to efficiently generate a triplet state which reacts with nearby molecular oxygen to generate cytotoxic singlet oxygen and/or other reactive oxygen species. Clinical photosensitizers are mainly porphyrin or chlorin derivatives, with a large hydrophobic aromatic core decorated with several hydrophilic groups to prevent their aggregation. ${ }^{38,39}$ Their amphiphilic character is of importance for tumor uptake and their excitation typically performed in the $630-690 \mathrm{~nm}$ range lies below the optical therapeutic window $(700-1000 \mathrm{~nm})$, restricting this light-activated therapy to superficial tumors. ${ }^{40}$ Therefore, different approaches to improve the efficiency of PDT are being explored..$^{146}$

MRI monitoring of the photosensitizer delivery to the site of interest and of the therapy outcome could contribute to more secure and accurate PDT treatment. Various nanomaterials were considered to carry and deliver large amounts of contrast agents and PDT photosensitizers. ${ }^{2.475 .5}$ Combining several Gd(III) complexes and typical photosensitizers within a single molecular entity could have mutually positive consequences for the physical and chemical properties of both components: on one hand, the hydrophilic character of the contrast agents will increase the water solubility of the photosensitizer, on the other hand, the elevated molecular weight will lead to improved proton relaxivity and MRI efficiency. So far, there have been only few literature reports on multifunctional molecular systems combining 
the appropriate features for MRI detection and PDT activity. ${ }^{53.60}$ In particular, Pandey's group has extensively investigated chlorophyll derivatives linked to three or six [GdDTPA $]^{2-}$ complexes and these systems have shown increased relaxivities thanks to their high molecular weight. ${ }^{54-56}$ The bifunctional agent with three $\mathrm{Gd}(\mathrm{III})$ complexes was a very promising candidate for theranostic applications as it demonstrated efficacy for both in vivo PDT and MR tumor imaging. Recently, we have reported a molecule, [DPP-ZnP-GdDOTA] ${ }^{-}$, which combines a diketopyrrolopyrrole-porphyrin component DPP-ZnP as a one- and two-photon photosensitizer for PDT with a [GdDOTA $]^{-}$complex. This conjugate was endowed with high relaxivity, low dark toxicity and was able to induce high one-photon and moderate twophoton phototoxicity on cancer cells. ${ }^{60}$

We report herein the synthesis and physicochemical characterization of the water-soluble molecule 1 consisting of a porphyrin core linked to four [GdDTTA] ${ }^{-}$complexes. Our specific objective was to optimize proton relaxivity, thus MRI efficiency and to have a good photosensitizing activity of the molecule for PDT. The corresponding diamagnetic compound 2 with four yttrium(III) complexes was also synthesized for analysis purposes. The photophysical properties, longitudinal relaxivity and in cellulo phototoxicity of the tetranuclear gadolinium(III) complex 1 were studied to assess its potential as a theranostic system that combines PDT and MR imaging capabilities. We demonstrate that the high rigidity of the molecule and the bishydration of the Gd(III) ions indeed confer a remarkable relaxivity to this system, while the favorable photophysical properties and the phototoxicity of the porphyrin core are also retained.

\section{Experimental section}

All reagents and solvents commercially available were used as received. ${ }^{H} \mathrm{H}$ and ${ }^{13} \mathrm{C} \mathrm{NMR}$ spectra and high-field relaxivity measurements were acquired on a Bruker AVANCE 300, 400,500 or 600 spectrometer. Chemical shifts are given in ppm with the residual solventproton as an internal reference $\left(\mathrm{CD}_{2} \mathrm{Cl}_{2}\right.$ at $\delta=5.32 \mathrm{ppm}, \mathrm{CDCl}_{3}$ at $\delta=7.26 \mathrm{ppm}, \mathrm{CD}_{3} \mathrm{CN}$ at $\delta=$ $1.94 \mathrm{ppm}$ ). For NMR samples measured in $\mathrm{D}_{2} \mathrm{O}$, chemical shifts are referred to tert- $\mathrm{BuOH}$ as the reference. In variable-temperature NMR studies, the value of the chemical shift of the HOD peak was corrected for the variation as a function of the temperature according to Nudelman's equation. ${ }^{11}$ Mass spectra were obtained by using a Bruker MicroTOF spectrometer (ES-MS). Dialysis devices [1000 molecular weight cutoff (MWCO)] were manufactured by Spectrum Laboratories, Inc. (Rancho Dominguez, CA). ICP-AES was 
performed by emission spectrometry with an ICP-AES Varian 720-ES spectrophotometer. ICP-MS was performed with an Agilent 7500ce spectrometer.

Synthesis of compound 5. To a solution of 3 (482 $\mathrm{mg}, 0.86 \mathrm{mmol})$ in DMF (6.8 $\mathrm{mL})$ under argon was added compound $2(170 \mathrm{mg}, 0.172 \mathrm{mmol})$ and $\mathrm{K}_{2} \mathrm{CO}_{3}(124 \mathrm{mg}, 0.89 \mathrm{mmol})$. The resulting suspension was stirred at room temperature overnight. After evaporation of the solvent, the residue was dissolved in $\mathrm{CH}_{2} \mathrm{Cl}_{2}(40 \mathrm{~mL})$ and washed with water $(3 \mathrm{x} 20 \mathrm{~mL})$. The organic phase was dried with $\mathrm{Na}_{2} \mathrm{SO}_{4}$. After filtration and evaporation of the solvent, the crude compound was purified by alumina column chromatography $\left(\mathrm{CH}_{2} \mathrm{Cl}_{2} / \mathrm{MeOH} 2 \%\right)$ to yield compound $\mathbf{5}$ (290 $\mathrm{mg}$ ) in 58\% yield.

'H NMR (400 MHz, $\left.\mathrm{CDCl}_{3}, 298 \mathrm{~K}\right): \delta-2.76\left(\mathrm{~s}, 2 \mathrm{H}, \mathrm{H}_{\mathrm{мн}}\right), 1.47(\mathrm{~s}, 144 \mathrm{H}, \mathrm{tBu}), 2.90\left(\mathrm{t},{ }^{3} J=7.0\right.$ $\mathrm{Hz}, 16 \mathrm{H}, \mathrm{H}_{2}$ or $\left.\mathrm{H}_{3}\right), 3.05\left(\mathrm{t},{ }^{3} \mathrm{~J}=7.0 \mathrm{~Hz}, 16 \mathrm{H}, \mathrm{H}_{2}\right.$ or $\left.\mathrm{H}_{3}\right), 3.55\left(\mathrm{~s}, 32 \mathrm{H}, \mathrm{H}_{4}\right), 4.01\left(\mathrm{~s}, 8 \mathrm{H}, \mathrm{H}_{1}\right), 7.70$ $\left(\mathrm{d},{ }^{3} \mathrm{~J}=7.9 \mathrm{~Hz}, 8 \mathrm{H}, \mathrm{H}_{\mathrm{m}}\right), 8.13\left(\mathrm{~d},{ }^{3} \mathrm{~J}=7.9 \mathrm{~Hz}, 8 \mathrm{H}, \mathrm{H}_{\mathrm{o}}\right), 8.86 \mathrm{ppm}\left(\mathrm{s}, 8 \mathrm{H}, \mathrm{H}_{\mathrm{pr}}\right)$.

${ }^{13} \mathrm{C}$ NMR (125 MHz, $\left.\mathrm{CDCl}_{3}, 298 \mathrm{~K}\right): \delta$ 28.37, 52.23, 53.19, 56.43, 59.09, 81.01, 120.16, $127.26,134.68,139.17,140.84,170.91 \mathrm{ppm}$.

UV-Vis (DCM): $\lambda_{\max }: 420,517,553,594,649 \mathrm{~nm}$.

ESI-MS: $m / z, 1451.39[\mathrm{M}+2 \mathrm{H}]^{2+} / 2\left(\right.$ calcd 1451.40 for $\left.\left[\mathrm{C}_{100} \mathrm{H}_{242} \mathrm{~N}_{10} \mathrm{O}_{32} \mathrm{H}_{2}\right]^{2+} / 2\right)$.

Synthesis of ligand 6 . Trifluoroacetic acid $(3 \mathrm{~mL})$ was added to a solution of 5 (290 $\mathrm{mg}, 0.10$ mmol) in $\mathrm{CH}_{2} \mathrm{Cl}_{2}(3 \mathrm{~mL})$ and the resulting green solution was stirred at room temperature overnight. After evaporation, $\mathrm{CH}_{2} \mathrm{Cl}_{2}(3 \mathrm{~mL})$ was added and the solvent was evaporated, this procedure was repeated twice. The crude compound was purified by cation-exchange resin (DOWEX 50WX2) followed by anion-exchange resin (AG1X2). After evaporation of the solvent, the white powder was dissolved in water $(5 \mathrm{~mL})$, the $\mathrm{pH}$ of the solution adjusted to 7 and dialyzed twice against distilled water and once against ultrapure water in a molecular weight cutoff (MWCO) of $1 \mathrm{kDa}$ membrane in order to remove the salts. After evaporation, compound 6 was obtained as a white powder in $80 \%$ yield $(228 \mathrm{mg})$.

'H NMR (300 MHz, $\mathrm{D}_{2} \mathrm{O}, 1 \%$ tert-BuOH, $\left.\mathrm{pD}=1.2,343 \mathrm{~K}\right): \delta 3.54\left(\mathrm{~s}, 16 \mathrm{H}, \mathrm{H}_{2}\right.$ or $\left.\mathrm{H}_{3}\right), 3.70$ (s, $16 \mathrm{H}, \mathrm{H}_{2}$ or $\left.\mathrm{H}_{3}\right), 3.86\left(\mathrm{~s}, 32 \mathrm{H}, \mathrm{H}_{4}\right), 4.89\left(\mathrm{~s}, 8 \mathrm{H}, \mathrm{H}_{1}\right), 8.28\left(\mathrm{~d}, 8 \mathrm{H},{ }^{3} \mathrm{~J}=8.1 \mathrm{~Hz}, \mathrm{H}_{\mathrm{m}}\right), 8.78(\mathrm{~d}, 8 \mathrm{H}$, $\left.{ }^{3} \mathrm{~J}=8.1 \mathrm{~Hz}, \mathrm{H}_{\circ}\right), 9.00 \mathrm{ppm}\left(\mathrm{s}, 8 \mathrm{H}, \mathrm{H}_{\mathrm{prr}}\right)$.

${ }^{13} \mathrm{C}$ NMR $\left(125 \mathrm{MHz}, \mathrm{D}_{2} \mathrm{O}, 1 \%\right.$ tert $\left.-\mathrm{BuOH}, \mathrm{pD}=1.2,298 \mathrm{~K}\right): \delta 50.98,51.18,56.10,58.86$, $122.96,130.66,131.44,134.40,136.17,139.92,140.88,145.79,172.88$ ppm.

'H DOSY (600 MHz, $\left.\mathrm{D}_{2} \mathrm{O}, 298 \mathrm{~K}\right): \mathrm{D}=1.49 \times 10^{-10} \mathrm{~m}^{2} \mathrm{~s}^{-1}$ 
UV-Vis $\left(\mathrm{H}_{2} \mathrm{O}, \mathrm{pH} 4.4\right): \lambda_{\max }=437,595,652 \mathrm{~nm}$

UV-Vis $\left(\mathrm{H}_{2} \mathrm{O}, \mathrm{pH} 9.4\right): \lambda_{\max }=414,514,553,580,633 \mathrm{~nm}$

HR ESI-MS: m/z $399.5519[\mathrm{M}-5 \mathrm{H}]^{\mathrm{s} /} / 5\left(\right.$ calcd 399.5473 for $\left.\left[\mathrm{C}_{96} \mathrm{H}_{109} \mathrm{~N}_{16} \mathrm{O}_{32}\right]^{\mathrm{s} / 15}\right)$

Synthesis of complexes 1 and 2. To a solution of $6(4 \mathrm{~mL}, 0.83 \mathrm{mM})$ in distilled water at $\mathrm{pH}$ 7 was added an aqueous solution of $\mathrm{Ln}\left(\mathrm{NO}_{3}\right)_{3}$ (in a 3.9/1 ratio) in six portions. The $\mathrm{pH}$ was adjusted to 6.5-7 using a solution of $\mathrm{NaOH} 1 \mathrm{M}$ after each addition. The resulting solution was stirred at room temperature overnight, and the $\mathrm{pH}$ was adjusted to 7 . The salts were removed by dialysis twice against distilled water and once against ultrapure water in a 1000 MWCO membrane. It has been possible to follow the complexation of 2 with yttrium(III) by ${ }^{\text {:C NMR }}$ in $\mathrm{D}_{2} \mathrm{O}$. The ${ }^{13} \mathrm{C}$ signal corresponding to the carboxylates at $172.88 \mathrm{ppm}$ is replaced by three signals at $179.34,180.44$ and $181.41 \mathrm{ppm}$ for the carboxylates coordinated to Y(III).

Characterization of 2.

'H NMR (400 MHz, D $20, \mathrm{pD}=7.0,363 \mathrm{~K}): \delta 1.50-3.50\left(\right.$ br m, 64H, $\left.\mathrm{H}_{2}, \mathrm{H}_{3}, \mathrm{H}_{4}\right), 4.00(\mathrm{~s}, 8 \mathrm{H}$, $\mathrm{H}_{1}$ ), 7.27 (br s, 8H, $\mathrm{H}_{\mathrm{m}}$ ), 7.85 (br s, 8H, $\mathrm{H}_{\circ}$ ), 8.79 ppm (br s, $8 \mathrm{H}, \mathrm{H}_{\mathrm{prr}}$ ).

${ }^{13} \mathrm{C}$ NMR $\left(125 \mathrm{MHz}, \mathrm{D}_{2} \mathrm{O}, \mathrm{pD}=7.0,298 \mathrm{~K}\right)$ : broad signals at $\delta 48.40,54.49,55.76,63.01$, $119.44,120.26,130.38,135.07,141.12,179.34,180.44,181.41$ ppm.

'H DOSY (600 MHz, D $\mathrm{O}, 298 \mathrm{~K}): \mathrm{D}=1.07 \times 10^{-10} \mathrm{~m}^{2} \mathrm{~s}^{-1}$ at $0.25 \mathrm{mM}$.

HR ESI-MS: m/z $585.8196\left[\mathrm{M}-8 \mathrm{H}_{2} \mathrm{O}\right]^{4 / 4}\left(\right.$ calcd 585.8194 for $\left.\left[\mathrm{C}_{96} \mathrm{H}_{98} \mathrm{~N}_{16} \mathrm{O}_{32} \mathrm{Y}_{4}\right]^{4 / 4}\right)$

UV-Vis $\left(\mathrm{H}_{2} \mathrm{O}, \mathrm{pH} 6.5\right): \lambda_{\max }: 414,517,554,581,636 \mathrm{~nm}$.

Characterization of $\mathbf{1}$.

HR ESI-MS: m/z $654.0933\left[\mathrm{M}-8 \mathrm{H}_{2} \mathrm{O}\right]^{4 / 4}\left(\right.$ calcd 654.0875 for $\left.\left[\mathrm{C}_{96} \mathrm{H}_{98} \mathrm{~N}_{16} \mathrm{O}_{32} \mathrm{Gd}_{4}\right]^{4} / 4\right)$

UV-Vis $\left(\mathrm{H}_{2} \mathrm{O}, \mathrm{pH} 7.0\right): \lambda_{\max }\left(\varepsilon / \mathrm{M}^{-1} \mathrm{~cm}^{-1}\right): 414$ (173200), 516 (5900), 554 (3300), 580 (2300), 634 $\mathrm{nm}(1700)$.

\section{Spectroscopy and Photophysics}

Tridistilled (Millipore Milli-Q) water was used as solvent, the $\mathrm{pH}$ was regularly adjusted to 7 with micro additions of diluted $\mathrm{NaOH}$ water solutions.

Absorption spectra were recorded with a Perkin-Elmer Lambda $650 \mathrm{UV}$-vis and with a Lambda 9 UV-vis-NIR spectrophotometers. Emission spectra were collected with an Edinburgh FLS920 fluorimeter equipped with a Peltier-cooled Hamamatsu R928 PMT (200$850 \mathrm{~nm}$ ), and corrected for the wavelength dependent phototube response. The fluorescence quantum yield of $\mathbf{1}$ in water has been determined with reference to TPP (tetra-phenyl- 
porphyrin) in aerated toluene as a standard $\left(\phi_{\mathrm{fl}}=0.11\right) .{ }^{62}$ The fluorescence lifetime was measured using an IBH 5000F Time Correlated Single Photon Counting apparatus with diode laser pulsed excitation source at $373 \mathrm{~nm}$. Estimated errors are $10 \%$ on lifetime, $20 \%$ on quantum yield, and $3 \mathrm{~nm}$ on emission and absorption peaks.

Singlet oxygen production quantum yield of $\mathbf{1}$ has been measured with a comparative method using anthracene-9, 10-dipropionic acid (ADPA) disodium salt as a singlet oxygen trap, which is oxidized by singlet oxygen and its degradation can be monitored by the decrease of its absorbance. ${ }^{63}$ The use of an indirect method was made necessary by the strict $\mathrm{pH}$ control required for compound $\mathbf{1}$, since the $\mathrm{pH}$ adjustment is easily obtained in water but less straightforward in $\mathrm{D}_{2} \mathrm{O}$, the solvent usually employed for direct singlet oxygen phosphorescence measurement in aqueous environments. 5,10,15,20-tetrakis (4sulphonatophenyl)-porphyrin (TPPS 4 , from Sigma-Aldrich) has been used as a standard ( $\phi_{\Delta}{ }^{S t d}$ $=0.51){ }^{6+65}$ Water solutions at $\mathrm{pH}=7$ of the standard or of 1 containing ADPA $3 \times 10^{-5} \mathrm{M}$, prepared in the dark, have been irradiated at $516 \mathrm{~nm}\left(A_{516}=0.3\right)$ by using an irradiation set-up composed by a $150 \mathrm{~W}$ Xenon lamp (LOT) and a Omni- $\lambda 150$ monochromator (Zolix) with a $16 \mathrm{~nm}$ slit and completed by a $500 \mathrm{~nm}$ cut-off filter, under continuous stirring. The light intensity was $2 \mathrm{~mW} / \mathrm{cm}^{2}$. The evolution of the absorption spectra of the mixtures containing either the standard or compound $\mathbf{1}$ and ADPA, upon irradiation at $516 \mathrm{~nm}$, is reported in Figure S24. The singlet oxygen quantum yield of the sample $\left(\phi_{\Delta}\right)$ has been determined by using equation (1):

$$
\Phi_{\Delta}=\Phi_{\Delta}^{S t d} \frac{R \cdot I_{a b s}^{S t d}}{R^{S t d} \cdot I_{a b s}}
$$

where $R$ and $R^{S t d}$ are the ADPA degradation rates for the sample and the standard, respectively, and $I_{a b s}$ is the absorption at the excitation wavelength calculated as the overlap integral of the source light intensity and the absorption spectrum of the compound in the irradiated spectral region. ${ }^{63}$ Control experiments were performed on samples bubbled with argon for ca. $15 \mathrm{~min}$ and sealed in homemade $10 \mathrm{~mm}$ optical path length cells before irradiation. A ca. 50\% reduction in the ADPA degradation rate was observed in degassed samples, a reasonable decrease considering the limited oxygen purging reachable with the employed procedure. ADPA thermal stability under the same experimental conditions was also assessed.

\section{Relaxometric measurements}


Proton NMRD profiles $\left([\mathbf{1}]=2.13 \mathrm{mM}, \mathrm{pH}=7.04\right.$ in $\mathrm{H}_{2} \mathrm{O}$, and $[\mathbf{1}]=1.36 \mathrm{mM}, \mathrm{pH}=6.60$ in aqueous $\mathrm{NaCl} 50 \mathrm{mM}$ ) were recorded on a Stelar SMARTracer Fast Field Cycling relaxometer (0.01-10 MHz) and a Bruker WP80 NMR electromagnet adapted to variable field measurements (20-80 MHz) and controlled by a SMARTracer PC-NMR console. Higher field relaxivities were measured on Bruker AVANCE NMR spectrometers at $300 \mathrm{MHz}, 400 \mathrm{MHz}$, and $600 \mathrm{MHz}$. The temperature was monitored by a VTC91 temperature control unit and maintained by a gas flow. The temperature was determined by previous calibration with a $\mathrm{Pt}$ resistance temperature probe. The longitudinal relaxation rates $\left(1 / \mathrm{T}_{1}\right)$ were determined in water and in aqueous $50 \mathrm{mM} \mathrm{NaCl}$. The least-squares fit of the ${ }^{1} \mathrm{H}$ NMRD data was performed using Visualiseur/Optimiseur ${ }^{66}$ running on a MATLAB 8.3.0 (R2014a) platform. The relaxivity was also measured in the presence of BSA $34 \mathrm{~g} . \mathrm{L}^{-1}$ for $[1]=0.272 \mathrm{mM}$, in $\mathrm{H}_{2} \mathrm{O}$ $\mathrm{pH}=7.2$, and $[\mathbf{1}]=0.136 \mathrm{mM}$ in Hepes $50 \mathrm{mM}, \mathrm{pH}=7.4$, at $298 \mathrm{~K}$ and $20 \mathrm{MHz}$. Concentration studies were performed in the range [1] $=2.13 \mathrm{mM}-0.11 \mathrm{mM}$ in $\mathrm{H}_{2} \mathrm{O}$, and [1] $=1.36 \mathrm{mM}-0.12 \mathrm{mM}$ in $50 \mathrm{mM} \mathrm{NaCl}$. The exact $\mathrm{Gd}(\mathrm{III})$ ion concentration was always determined by ICP-AES analysis.

\section{T1-weighted phantom MR images}

The MRI experiments were performed on a $7 \mathrm{~T}$ Biospec 70/30 USR NMR spectrometer (Bruker, Ettlingen, Germany) at $20^{\circ} \mathrm{C}$. They were carried using a circular polarized transmit/receive $1 \mathrm{H}$ volume coil with an inner diameter of $72 \mathrm{~mm}$.

For the aqueous solution imaging, $\mathrm{T}_{1}$-weighted spin-echo images $(\mathrm{TR} / \mathrm{TE}=260.2 / 5.9 \mathrm{~ms}$, $\mathrm{FA}=90 / 180.0^{\circ}$ ) of a single $1 \mathrm{~mm}$ slice, pixel size $313 \times 313 \mu \mathrm{m}^{2}$, were acquired in axial orientation. $T_{1}$ measurements were realized with a RARE-VTR sequence, and 24 TRs (16.4, 135.5, 260.2, 391.0, 528.3, 673.1, 826.1, 988.2, 1160.7, 1345.0, 1542.8, 1756.2, 1988.0, 2241.5, 2521.4, 2833.6, 3186.7, 3593.1, 4071.6, 4653.6, 5396.6, 6425.0, 8106.9 and 13500 $\mathrm{ms}) ; \mathrm{TE}=5.9 \mathrm{~ms}, \mathrm{FA}=90 / 180.0^{\circ}$; and a single $1 \mathrm{~mm}$ slice, pixel size $313 \times 313 \mu \mathrm{m}^{2}$, scan time $2 \mathrm{~h} 25 \mathrm{~m} 22 \mathrm{~s}$.

For the cell pellets imaging, $\mathrm{T}_{1}$ measurements were performed with a RARE-VTR sequence, and 20 TRs (46.82 191.77344 .95507 .34680 .14864 .751062 .911276 .781509 .061763 .22 2043.812356 .982711 .33119 .243599 .984185 .274933 .595972 .387682 .62 and $13500 \mathrm{~ms}$ ); $\mathrm{TE}=6 \mathrm{~ms}, \mathrm{FA}=90 / 180.0^{\circ}$; and three $0.5 \mathrm{~mm}$ slices, pixel size $300 \times 300 \mu \mathrm{m}^{2}$, scan time $1 \mathrm{~h} 37$. All quantitative T1 maps were calculated assuming exponential regrowth, using ImageJ (ImageJ version, 1.50e NIH). 


\section{Cell culture}

HeLa cells were cultured in DMEM complete culture medium containing phenol red at $37^{\circ} \mathrm{C}$ with $5 \% \mathrm{CO}_{2}$. They were seeded and maintained in $25 \mathrm{~mL}$ Falcon culture flask or multi well LabTek (Lab-Tek ${ }^{\circledR}$ II) culture flasks. MTT toxicity tests were performed in tetraplicate with extemporaneous solutions of 3-(4,5-Dimethyl-2-thiazolyl)-2,5-diphenyl-2H-tetrazolium bromide ( $50 \mu \mathrm{L}$ of a $5 \mathrm{mg} / \mathrm{mL}$ solution in DMEM by well). After an incubation period of 2 hours, the media was removed and replaced by $150 \mu \mathrm{L}$ of DMSO. The absorbance was measured in 96 well plates with a Safas Xenius spectrofluorimeter at $550 \mathrm{~nm}$.

\section{Cells preparation for $\mathbf{T}_{1}$-weighted phantom $M R$ images}

HeLa cells were seeded in $250 \mathrm{~mL}$ culture flask in complete DMEM medium as described previously in the cell culture paragraph. Samples of these cultures were incubated with $\mathbf{1}(0$, $2.5 \mu \mathrm{M}, 6 \mu \mathrm{M}$ and $10 \mu \mathrm{M})$ for 24 hours. These cell cultures were then washed three times with PBS $(15 \mathrm{~mL})$. Cells were suspended using trypsin $(1 \mathrm{~mL})$ and $9 \mathrm{~mL}$ of DMEM were added. The cells were counted using a Malassez cell. The culture medium was removed by gentle centrifugation at $60 \times \mathrm{g}$. The pellets were suspended in a $1.5 \mathrm{~mL}$ Eppendorf tube filled with DMEM and centrifuged again at $60 \times \mathrm{g}$, to afford pellets in the bottom of the Eppendorf tubes which were imaged.

\section{ICP measurements}

The Gd content in aqueous samples was determined by ICP-AES after mineralization in a microwave oven Anton Paar: multiwave ECO 3000 in a nitric acid solution $\left(\mathrm{HNO}_{3}\right.$ for trace analysis $\geq 69.0 \%$, TraceSELECT $\AA$, from Fluka).

The Gd content in cell was determined by ICP-MS from the known number of cells contained in an Eppendorf tube. The cell pellet samples were transferred in a $10-\mathrm{mL}$ container with a $60 \%$ nitric acid solution and digested for 24 hours at room temperature, followed if necessary by heating at $50^{\circ} \mathrm{C}$ for 24 hours.

\section{One-photon phototoxicity tests}

One-photon phototoxicity tests were performed as described in the literature using a homemade apparatus ${ }^{67}$ using $5 \mathrm{~mm} 636 \mathrm{~nm} 1100$ mcd LED (Mouser electronics ref. 696-SSLLX509E3SIT) adapted for black Corning ${ }^{\circledR} 96$ well special optics plates. Cells were cultured 2 
days in these 96 well plates and incubated with 2.5 and $6 \mu \mathrm{M}$ solution of photosensitizer in complete DMEM medium for 24 hours. The plates were irradiated for 1 hour and the light intensity was measured with a power-meter for each well. The cell viability was estimated 5 hours after irradiation as described in cell culture paragraph.

\section{Results and discussion}

\section{Synthesis}

The sequence of chemical reactions leading to the target molecule $\mathbf{1}$ and to the related diamagnetic compound $\mathbf{2}$ is depicted in Figure 1. A convergent synthetic approach was chosen to assemble four protected DTTA chelates $\mathbf{4}$ on the central tetraphenylporphyrin core through a relatively rigid linker. The benzyl linker minimizes rotational flexibility and thus allows optimization of the relaxivity gain brought by the increase of the molecular weight. The $\mathrm{H}_{4}$ DTTA chelate has been first explored by $\mathrm{us}^{22 \cdot 26}$ and then by others as well ${ }^{18.72}$ and presents several advantages with regard to MRI contrast agent applications. This heptadentate ligand allows the coordination of two inner-sphere water molecules to complete the coordination sphere of the $\mathrm{Gd}(\mathrm{III})$ ion, which doubles the inner-sphere contribution to the relaxivity. It guarantees a relatively fast water exchange, as has been evidenced for numerous systems bearing this chelate. ${ }^{23,73}$ The two water molecules are not substantially replaced by endogenous anions. ${ }^{74}$ In addition, the grafting of several [GdDTTA] complexes to different central scaffolds has resulted in medium-sized MRI probes showing high relaxivities over a broad range of magnetic field. ${ }^{22,2426}$ Finally, MR imaging studies of some of these agents in mice proved non-toxicity and that the high relaxivity is retained in vivo as well. ${ }^{24,74}$

The porphyrin precursor 3 was obtained in good yield (60\%) following literature procedure. ${ }^{75}$ The protected chelate 4 was prepared in a succession of protection/deprotection steps. ${ }^{76}$ Nucleophilic substitution of porphyrin 3 with 4 in the presence of $\mathrm{K}_{2} \mathrm{CO}_{3}$ afforded compound 5 in 58\% yield after purification by alumina column chromatography. The tert-butyl ester protecting groups were removed with TFA and the resulting hydrophilic porphyrin 6 bearing four $\mathrm{H}_{4}$ DTTA chelates was purified on cation- and anion-exchange resins. Compound 6 was fully characterized by 'H and ${ }^{\text {"C }}$ NMR spectroscopy, HR-MS and UV-vis absorption spectroscopy. 


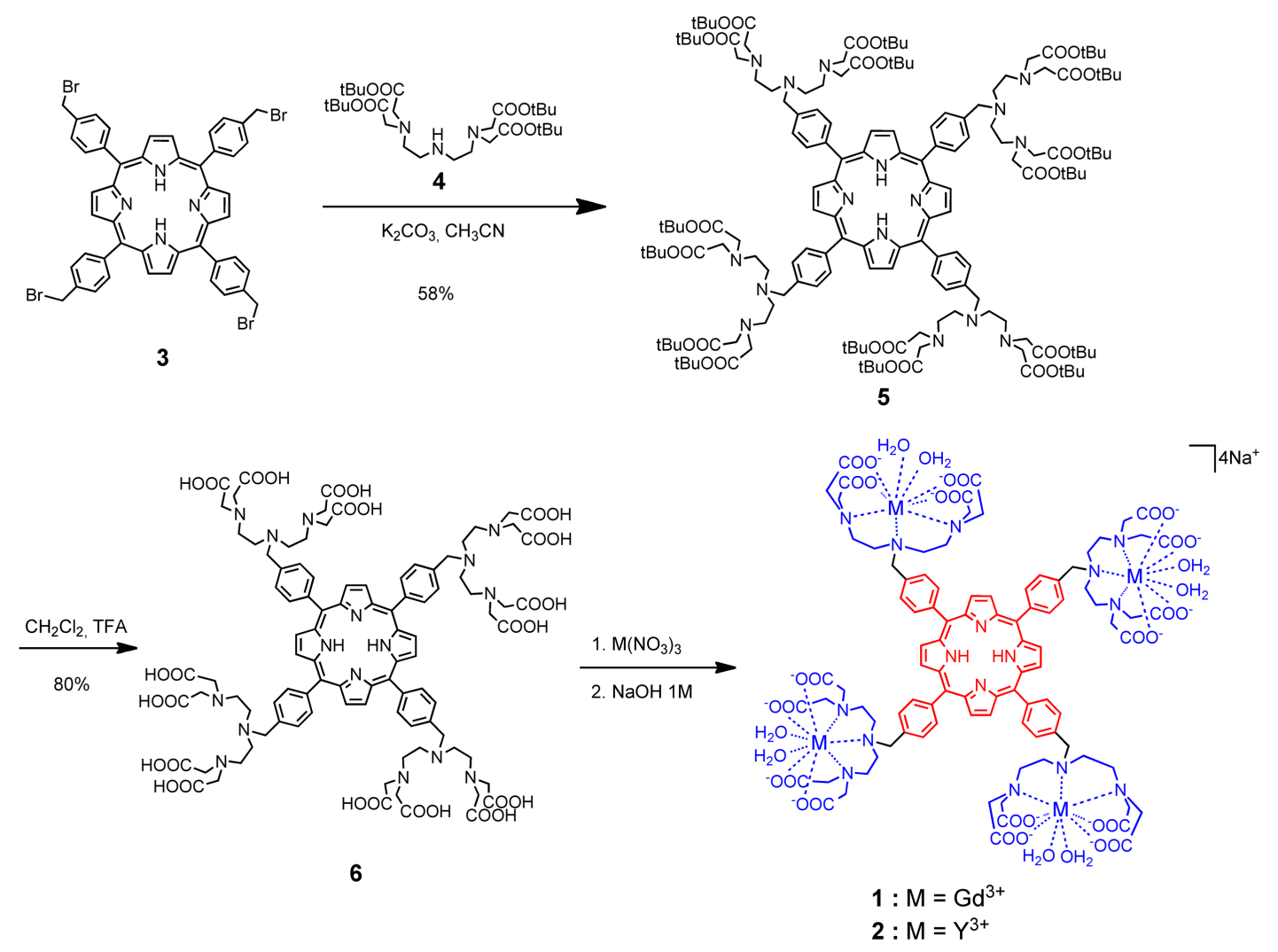

Figure 1. Synthesis of the tetranuclear Gd(III) and Y(III) complexes 1 and 2.

Synthesis of the gadolinium(III) and yttrium(III) complexes $\mathbf{1}$ and $\mathbf{2}$ were performed with the same stock solution of compound 6. An aqueous solution of known concentration of $\operatorname{Ln}\left(\mathrm{NO}_{3}\right)_{3}$ was added to an aqueous solution of 6 while adjusting the $\mathrm{pH}$ to 6.5-7 using $1 \mathrm{M} \mathrm{NaOH}$. To ensure the absence of free $\operatorname{Ln}(\mathrm{III})$, the complexation was performed by mixing the metallic ion with ligand 6 in a $3.9 / 1$ molar ratio which corresponds to a $2.5 \%$ excess of ligand. The salts were removed by dialysis against water, affording the gadolinium(III) and yttrium(III) complexes 1 and 2. For each complex, the molecular ion at $\left[\mathrm{M}-8 \mathrm{H}_{2} 0\right]^{4 / 4}$ was detected by high resolution ESI-MS with an isotopically resolved profile that fits with the calculated theoretical profile of the -4 charged species. (see Figures S12 and S13).

\section{Relaxivity properties}

To characterize the relaxation efficiency of compound 1, nuclear magnetic relaxation dispersion (NMRD) profiles were recorded at two different temperatures, in the $10 \mathrm{kHz}-600$ $\mathrm{MHz}$ field range both in $\mathrm{H}_{2} \mathrm{O}$ (Figure 2) and in an aqueous solution containing $50 \mathrm{mM} \mathrm{NaCl}$ (See Figure S14). We assumed that complex 1 has two inner-sphere water molecules per $\mathrm{Gd}^{3+}$ as it is the case for the [GdDTTA] complex..$^{2226}$ The relaxivity attained is $48.59 \mathrm{mM}^{-1} . \mathrm{S}^{-1}$ per 
$\mathrm{Gd}(\mathrm{III})$ at $40 \mathrm{MHz}, 25^{\circ} \mathrm{C}$, which is highly impressive even for a bishydrated complex. This is more than three times higher than the values observed for a similar porphyrin compound bearing four [GdDTTA] complexes ${ }^{s 8}$ and nearly ten times higher than the relaxivity reported for a porphyrin decorated with four monohydrated GdDO3A-monoamide chelates ${ }^{33}$ (see Table 1). Compared to other porphyrin systems containing one or several monohydrated complexes, the relaxivity of $\mathbf{1}$ is higher at least by a factor of 2 . To the best of our knowledge, among multimeric systems, this complex displays one of the highest relaxivities ever reported. 
Table 1. Relaxivity (per Gd) measured at $25^{\circ} \mathrm{C}, 20 \mathrm{MHz}$ (or otherwise stated) for various porphyrin-derivatives and other types of multimeric complexes of medium size.

\begin{tabular}{|c|c|c|c|c|c|}
\hline & Complex & $\begin{array}{l}\mathrm{Nb} \text { of } \mathrm{Gd} \\
\text { complexes }\end{array}$ & $q$ & $\begin{array}{l}\boldsymbol{r}_{1} \\
\left(\mathrm{mmol}^{-1} \cdot \mathrm{S}^{-1}\right)\end{array}$ & References \\
\hline \multirow[t]{8}{*}{$\begin{array}{l}\text { Porphyrinic } \\
\text { systems }\end{array}$} & 1 & 4 & 2 & 43.7 & $\begin{array}{l}\text { This work, in } \\
\mathrm{H}_{2} \mathrm{O}\end{array}$ \\
\hline & $\left.\mathrm{TPP}_{(\mathrm{GdDTTA}}\right)_{4}$ & 4 & 2 & 14.1 & Chen et al..$^{58}$ \\
\hline & $(\text { GdDO3A-amide })_{4}-\mathrm{H}_{2}$ (Porph) & 4 & 1 & 5.0 & Gros et al..$^{33}$ \\
\hline & [DPP-ZnP-GdDOTA] & 1 & 1 & 19.9 & Heitz et al..$^{60}$ \\
\hline & (GdDO3A-amide)- $\mathrm{H}_{2}$ (Porph) & 1 & 1 & 18.9 & Gros et al..$^{32}$ \\
\hline & $(\text { GdDO3A-amide })_{2}-\mathrm{H}_{2}$ (Porph) & 2 & 1 & 7.3 & Gros et al..$^{33}$ \\
\hline & (GdDO3A-amide) $)_{2}-\mathrm{H}_{2}$ (Porph') & 2 & 1 & 19.8 & Gros et al..$^{33}$ \\
\hline & 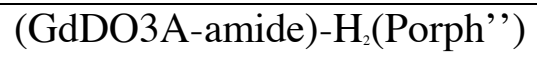 & 1 & 1 & 19.5 & Gros et al..$^{33}$ \\
\hline \multirow{7}{*}{$\begin{array}{l}\text { Other } \\
\text { multimeric } \\
\text { complexes }\end{array}$} & $\mathrm{Gd}_{2}\left(\mathrm{pX}(\mathrm{DTTA})_{2}\right.$ & 2 & 2 & 16.8 & $\begin{array}{l}\text { Merbach et } \\
\text { al. }^{23}\end{array}$ \\
\hline & $\mathrm{Ph}_{4}(\mathrm{GdDTTA})_{3}$ & 3 & 2 & 25.0 & Helm et al.$^{9}$ \\
\hline & $\begin{array}{l}(\mathrm{GdDTPA})_{4}-\mathrm{L} \\
(\mathrm{L}=\text { small polyamide })\end{array}$ & 4 & 1 & 11.3 & $\begin{array}{l}\text { Caravan et } \\
\text { al. } .^{77}\end{array}$ \\
\hline & $\begin{array}{l}\text { EP-2104R } \\
=(\text { GdDOTA })_{4} \text {-protein probe }\end{array}$ & 4 & 1 & $38.2^{\mathrm{a}}$ & $\begin{array}{l}\text { Caravan et } \\
\text { al. }^{78}\end{array}$ \\
\hline & $(\mathrm{GdL})_{6}-\alpha-\mathrm{CD}$ & 6 & 1 & 21.0 & Kotek et al. ${ }^{79}$ \\
\hline & $\begin{array}{l}\left\{\mathrm{Fe}\left[\mathrm{Gd}_{2} \mathrm{bpy}(\mathrm{DTTA})_{2}\left(\mathrm{H}_{2} \mathrm{O}\right)_{4}\right]_{3}\right\}^{4-} \\
\text { ("metallostar") }\end{array}$ & 6 & 2 & 27.0 & $\begin{array}{l}\text { Merbach et } \\
\text { al. }^{24}\end{array}$ \\
\hline & G3-(GdDO3A $)_{23}$ & 23 & 1 & $14.6^{b}$ & $\begin{array}{l}\text { Merbach et } \\
\text { al. }{ }^{80}\end{array}$ \\
\hline
\end{tabular}

a. At $60 \mathrm{MHz}, 37^{\circ} \mathrm{C}$; b. At $20 \mathrm{MHz}, 37^{\circ} \mathrm{C}$

Even more remarkable is the relaxivity obtained at high magnetic fields, $8.84 \mathrm{mM}^{-1} \cdot \mathrm{s}^{-1}$ and 4.82 $\mathrm{mM}^{-1} \cdot \mathrm{s}^{-1}$ at $300 \mathrm{MHz}$ and $600 \mathrm{MHz}$, respectively, in $\mathrm{H}_{2} \mathrm{O}$ at $25^{\circ} \mathrm{C}$. These values are only slightly lower than those reported for the $\left\{\mathrm{Fe}\left[\mathrm{Gd}_{2} \mathrm{bpy}(\mathrm{DTTA})_{2}\left(\mathrm{H}_{2} \mathrm{O}\right)_{4}\right]_{3}\right\}^{-4}$ metallostar endowed with exceptionally high field relaxivity $\left(r_{1}=9.3 \mathrm{MHz}\right.$ at $400 \mathrm{MHz}$ in $\mathrm{H}_{2} \mathrm{O}$ at $\left.25^{\circ} \mathrm{C}\right){ }^{24}$ The medium size contrast agent 1 is interesting for high magnetic field applications given the 
availability of clinical and research scanners operating above $3 \mathrm{~T}$ and the low efficiency of the common contrast agents at these fields. It is also interesting to compare the mass relaxivity or density of relaxivity, which is the enhancement of the relaxation rate per unit of molecular mass of the contrast agent as defined in equation 1:

$$
\text { density of relaxivity }=\frac{r_{1} n_{\mathrm{Gd}}}{M_{\mathrm{w}}} \times 1000
$$

where $n_{\mathrm{Gd}}$ is the number of $\mathrm{Gd}(\mathrm{III})$ ions per molecule and $M_{\mathrm{w}}$ is the molecular weight of the complex. The complex 1 has an impressive efficacy per unit of mass; 50\% higher than that reported for the Fe(II)-core metallostar ${ }^{24}\left(66.3(\mathrm{~g} / \mathrm{L})^{-1} \cdot \mathrm{S}^{-1}\right.$ vs. $43.7(\mathrm{~g} / \mathrm{L})^{-1} \cdot \mathrm{S}^{-1}$ at $\left.20 \mathrm{MHz}, 25^{\circ} \mathrm{C}\right)$, which implies a very high relaxation efficiency confined into a small molecular mass.

In order to check that aggregation is not an important factor to induce the high relaxivity attained, the paramagnetic relaxation enhancement (PRE) has been measured at $40 \mathrm{MHz}$ as a function of the concentration of 1 . In the range explored, 0.1-2.3 $\mathrm{mM}$ in $\mathrm{H}_{2} \mathrm{O}$, the PRE increases linearly with Gd(III) concentration, excluding important aggregation processes (see Figure S15). DOSY NMR experiments in the 0.2-1 $\mathrm{mM}$ range corroborated the absence of significant aggregation since only a slight decrease in the diffusion coefficient for compound 2 was observed upon 4-fold increase of the concentration (see Figures S5 and S6). The relaxivities obtained in $50 \mathrm{mM} \mathrm{NaCl}$ are slightly higher than those in $\mathrm{H}_{2} \mathrm{O}, r_{1}=56.38 \mathrm{mM}^{-1} \cdot \mathrm{S}^{-1}$ and $48.59 \mathrm{mM}^{-1} \cdot \mathrm{S}^{-1}$ at $40 \mathrm{MHz}, 25^{\circ} \mathrm{C}$, respectively, pointing to some aggregation in the presence of the salt. This is consistent with the observation that higher ionic strength favors aggregation of anionic porphyrins. ${ }^{81}$ Nevertheless, the system is probably mainly in the monomeric form as the relaxivity difference between $\mathrm{H}_{2} \mathrm{O}$ and $50 \mathrm{mM} \mathrm{NaCl}$ solutions is not significant, and the PRE is also linear in the concentration range studied in the presence of $\mathrm{NaCl}$ (although the best fit curve does not intercept zero, pointing to a slight aggregation, see Figure S16). It should be noted that we also observed a $10-15 \%$ increase of relaxivity compared to $\mathrm{H}_{2} \mathrm{O}$ when Hepes buffer was used $\left(r_{\text {IHpose }}=49.7 \mathrm{mM}^{-1} \cdot \mathrm{s}^{-1} v s r_{\text {1н20 }}=43.7 \mathrm{mM}^{-1} \cdot \mathrm{s}^{-1}\right.$ at 20 $\left.\mathrm{MHz}, 25^{\circ} \mathrm{C}\right)$.

In order to gain a better insight into the origin of the very high relaxivity measured for $\mathbf{1}$, the microscopic parameters characterizing rotational dynamics have been assessed by fitting the experimental field- and temperature-dependent relaxivity data to the Solomon-BloembergenMorgen (SBM) theory. To take into account internal dynamics, we incorporated in the fit the Lipari-Szabo treatment, often used to describe rotational motion of slowly (ns) tumbling species. $^{82}$ In this approach, the dipolar interactions between the Gd(III) electron spin and the 
water proton that generate the relaxation are influenced by both fast local rotational motion of the $\mathrm{Gd}(\mathrm{III})$-water proton vector, characterized by the correlation time $\tau_{\mathrm{Rl}}$, and a slower, global motion (characterized by $\tau_{\mathrm{Rg}}$ ) that reflects the global motion of the system. The degree of spatial restriction of the local with respect to the global motion is measured by the generalized, model-independent order parameter $S^{2}$. The value of $S^{2}$ ranges from 0 to 1 , with $S^{2}=0$ if the internal motions are isotropic, and $S^{2}=1$ if the internal motions are completely restricted. ${ }^{19}$ The fitting has been restricted to frequencies above $6 \mathrm{MHz}$ as at low magnetic fields the SBM theory fails in describing electronic parameters and rotational dynamics of slowly rotating objects. In the fitting procedure, the number of water molecules directly coordinated to $\mathrm{Gd}(\mathrm{III})$ was fixed to 2 , and the water exchange rate constant and its activation enthalpy $\left(k_{\mathrm{ex}}\right.$ and $\left.\Delta \mathrm{H}^{\neq}\right)$were fixed to values determined for [GdDTTA]. ${ }^{24,71}$ The diffusion coefficient for diffusion of a water proton away from a Gd(III) complex (approximately the sum of the diffusion coefficient of water and that of the complex), which is important to describe the outer sphere relaxivity contribution, was fixed to $D_{\mathrm{GdH}^{298}}=26 \times 10^{-10} \mathrm{~m}^{2} \mathrm{~s}^{-1}$.

The best-fit parameters obtained from the analysis of ${ }^{1} \mathrm{H}$ NMRD data are summarized in Table 2 and Table S1 and the fitted curves are presented in Figure 2. We checked that reasonable variations of $k_{\mathrm{ex}}$ do not affect the values of the parameters describing the rotational dynamics. It should be noted that the parameters characterizing electron spin relaxation are poorly determined by this fit and should not be over-interpreted. In Table 2, we compare our data to those recently reported for a Zn-porphyrin bearing one $\mathrm{Gd}(\mathrm{III})$ complex ${ }^{60}$ developed as a theranostic agent for PDT and MRI and to the metallostar $\left\{\mathrm{Fe}\left[\mathrm{Gd}_{2} \mathrm{bpy}(\mathrm{DTTA})_{2}\left(\mathrm{H}_{2} \mathrm{O}\right)_{4}\right]_{3}\right\}^{4-}$ 73 compound which is a discrete molecular contrast agent with six [GdDTTA] ${ }^{-}$complexes conjugated to an iron(II)-tris(bipyridine) complex. 


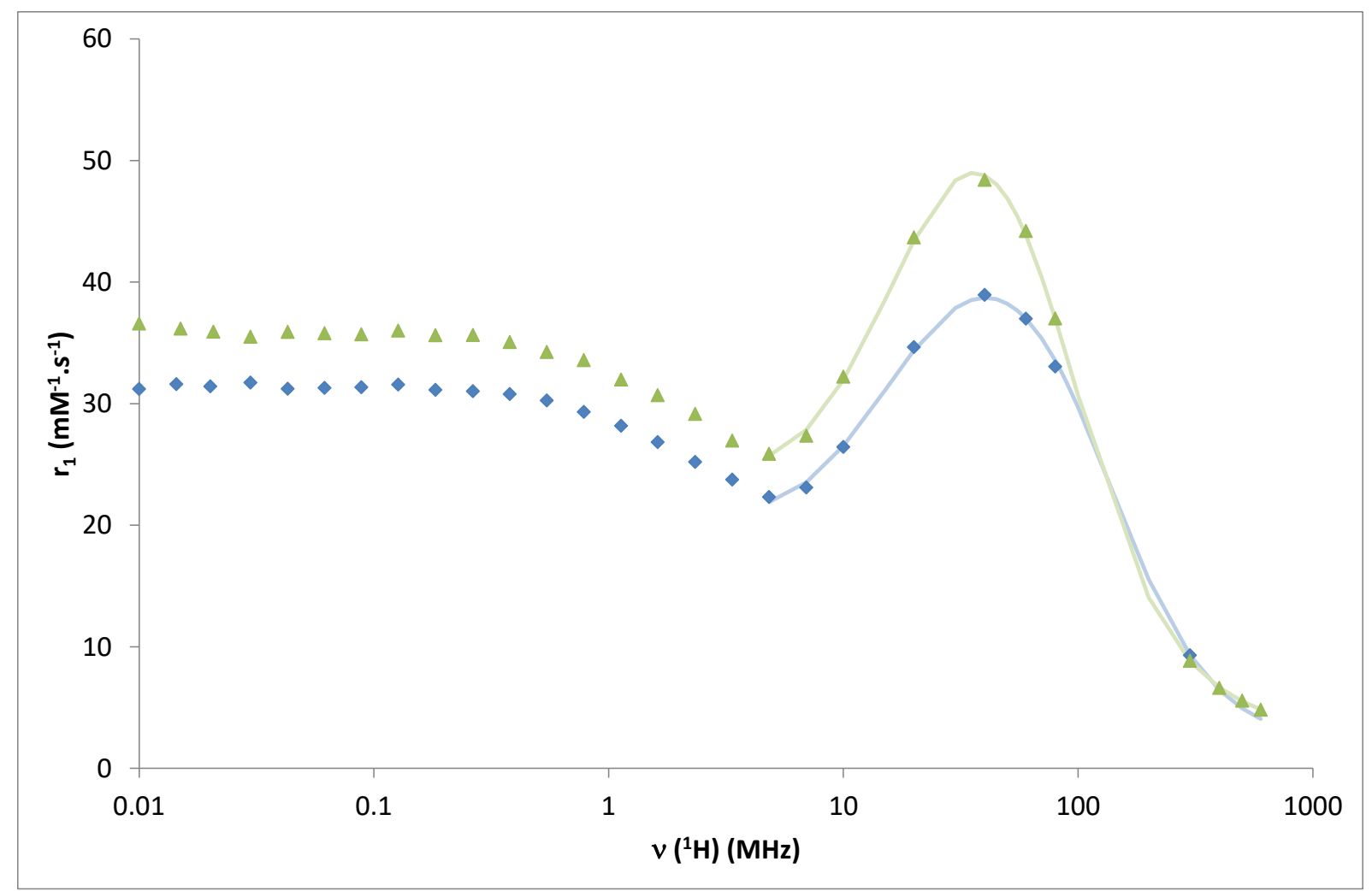

Figure 2. 'H Nuclear Magnetic Relaxation Dispersion (NMRD) profiles for 1 at $25^{\circ} \mathrm{C}(\Delta)$ and $37^{\circ} \mathrm{C}(\diamond)$ in $\mathrm{H}_{2} \mathrm{O}$. The continuous lines represent the best fitted curves to the SolomonBloembergen-Morgan (SBM) theory as described in the text.

Table 2. Best-fit parameters obtained from the fitting of the 'H NMRD profiles (Figure 2 and Figure S14) to the SBM theory, including the Lipari-Szabo approach to describe internal flexibility.

\begin{tabular}{|c|c|c|c|c|}
\hline Parameters & 1 in $\mathrm{H}_{2} \mathrm{O}$ & $\begin{array}{c}1 \text { in aqueous } \\
\mathrm{NaCl}(50 \\
\mathrm{mM})\end{array}$ & 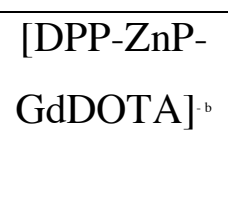 & $\begin{array}{c}\left\{\mathrm{Fe}\left[\mathrm{Gd}_{2} \mathrm{bpy}(\mathrm{DTTA})_{2}(\right.\right. \\
\left.\left.\left.\mathrm{H}_{2} \mathrm{O}\right)_{4}\right]_{3}\right\}^{4} \\
\text { ("metallostar") }\end{array}$ \\
\hline$M_{w}\left(\mathrm{~g} \cdot \mathrm{mol}^{-1}\right)$ & 2761 & 2761 & 2471 & 3744 \\
\hline $\begin{array}{c}r_{1}\left(\mathrm{mM}^{-1} \cdot \mathrm{s}^{-1} ; 40 \mathrm{MHz}\right. \\
\left.25^{\circ} \mathrm{C}\right)\end{array}$ & 48.59 & 56.38 & 18.61 & 33.6 \\
\hline$q^{a}$ & 2 & 2 & 1 & 2 \\
\hline$k_{\mathrm{ex}}^{298}\left(10^{6} \mathrm{~s}^{-1}\right)^{\mathrm{a}}$ & 8.3 & 8.3 & 4.1 & 7.4 \\
\hline$\Delta H^{\neq}\left(\mathrm{kJ} \cdot \mathrm{mol}^{-1}\right)^{\mathrm{a}}$ & 40 & 40 & 49.8 & 41.3 \\
\hline$E_{1}\left(\mathrm{~kJ} \cdot \mathrm{mol}^{-1}\right)$ & $40 \pm 9$ & $40 \pm 9$ & 40 & - \\
\hline$\tau_{1}^{298}(\mathrm{ps})$ & $94 \pm 5$ & $107 \pm 20$ & 245 & 190 \\
\hline
\end{tabular}




\begin{tabular}{|c|c|c|c|c|}
\hline$E_{\mathrm{g}}\left(\mathrm{kJ} . \mathrm{mol}^{-1}\right)$ & $29 \pm 2$ & $31 \pm 9$ & 14 & - \\
\hline$\tau_{\mathrm{g}}{ }^{298}(\mathrm{ps})$ & $1950 \pm 50$ & $2340 \pm 120$ & 2640 & 930 \\
\hline$S^{2}$ & $0.60 \pm$ & $0.66 \pm 0.02$ & 0.26 & 0.6 \\
& 0.08 & & & \\
\hline
\end{tabular}

${ }^{a}$ fixed in the fit; ${ }^{b}$ see reference ${ }^{60}$; ${ }^{c}$ see reference ${ }^{73}$

The global and local rotational correlation times obtained are higher in $\mathrm{NaCl}$ than in water, confirming a slight extent of aggregation in $\mathrm{NaCl}$ that results in higher relaxivities.

The value of $S^{2}$ is very high, higher than that reported for [DPP-ZnP-GdDOTA], and in the same order of magnitude as that of the metallostar. This is consistent with the high rigidity of 1, for which the only flexibility point is the $\mathrm{CH}_{2}$ group linking the $\mathrm{Gd}$ (III) complex to the phenylporphyrin. The same kind of flexibility was observed for the metallostar in which each rigid bipyridine ligand is linked through methylene groups to two [GdDTTA] complexes. The high relaxivity of $\mathbf{1}$ can thus be related to its high rigidity, combined with the bishydration of the Gd(III) ion. The overall size and shape of complex 1, imposed by the large and planar porphyrin central core is also an important factor, as it leads to a considerably longer global rotational correlation time $\tau_{\mathrm{g}}$ than the one of the very compact metallostar constructed on an octahedral Fe(II) complex, despite the smaller molecular weight of $\mathbf{1}$.

The considerably higher relaxivity of $\mathbf{1}$ as compared to TPP(GdDTTA $)_{4}$ reported by Chen and coworkers $^{\text {ss }}$ is certainly related to the difference in the rigidity of the two systems. Compound 1 has a short and rigid benzyl linker between the porphyrin and the Gd(III) complex, in contrast to the long and more flexible N-ethyl-2-phenoxyacetamide linker in TPP(GdDTTA) . It should be noted that even with this high rigidity, the relaxivity of $\mathbf{1}$ is still limited by rotation and not by water exchange rate, as shown by the relaxivity decrease upon increasing temperature..$^{15}$

In vivo, relaxivity can be enhanced by non-covalent interactions with macromolecules such as serum albumin, a protein present at high concentration in blood plasma. ${ }^{83}$ Compound $\mathbf{1}$ also forms adducts with Bovine Serum Albumin (BSA), as evidenced by the higher relaxivity values observed (27\% increase in $\mathrm{H}_{2} \mathrm{O}$ and $17 \%$ increase in Hepes, see Table S2) in the presence of physiological concentration of BSA (34 g. $\left.\mathrm{L}^{-1}\right)$. The difference observed between $\mathrm{H}_{2} \mathrm{O}$ and Hepes samples is likely due to a difference of affinity of BSA between monomeric (in $\mathrm{H}_{2} \mathrm{O}$ ) and slightly aggregated states (in Hepes). 
$\mathrm{T}_{1}$ maps of phantom were recorded at $7 \mathrm{~T}$, for compound $\mathbf{1}$ and for [GdDTPA] $]^{2-}$ (Figure 3). Even at this high magnetic field and at low micromolar concentration, compound 1 revealed a lower $\mathrm{T} 1$ value compared to $[\mathrm{GdDTPA}]^{2-}$. The determination of the relaxivity from the concentration dependent $T_{1}$ measurements in the MRI phantoms is reported Figure S17. The slope, which is much higher for compound 1, corresponds to the relaxivity. Indeed, even at 7 $\mathrm{T}$, the relaxivity is considerably higher for compound $\mathbf{1}\left(r_{1}=8.68 \mathrm{mM}^{-1} \mathrm{~s}^{-1}\right)$ than for $[\operatorname{GdDTPA}]^{2-}\left(r_{1}=3.58 \mathrm{mM}^{-1} \mathrm{~s}^{-1}\right)$, the difference being related to the two inner-sphere water molecules, but also to the medium size of compound $\mathbf{1}$ which is in the optimal range to maximize relaxivity at high fields.

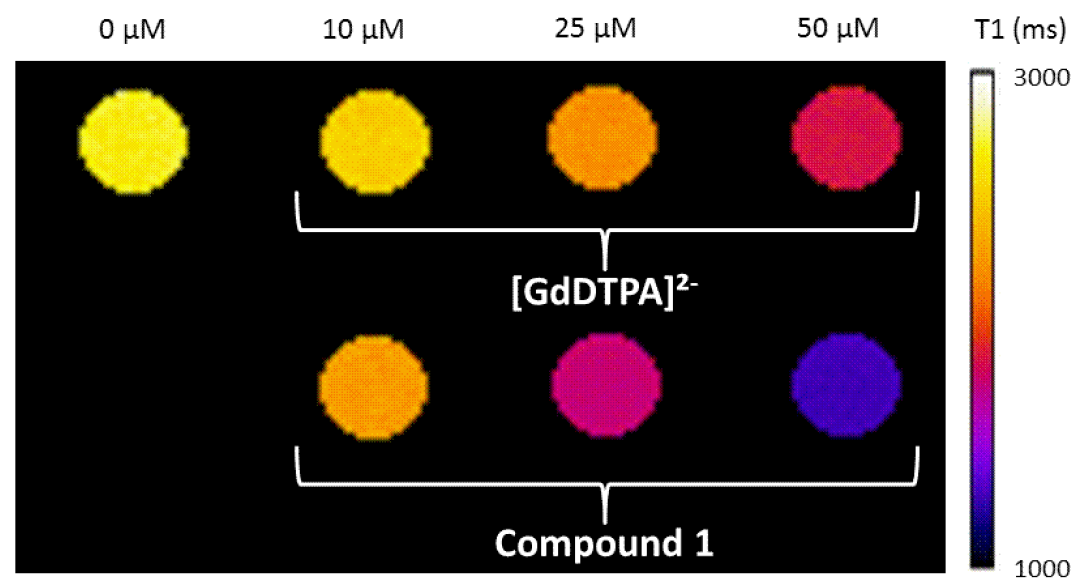

Figure 3. $\mathrm{T}_{1}$ maps of phantom at $7 \mathrm{~T}$ and $20^{\circ} \mathrm{C}$ as a function of $\mathrm{Gd}(\mathrm{III})$ concentration in aqueous $50 \mathrm{mM} \mathrm{NaCl}$ solution for [GdDTPA] $]^{2-}$ (top) and for compound $\mathbf{1}$ (bottom).

\section{Photophysical properties}

Absorption and emission properties of compound $\mathbf{1}$ have been examined in water at $\mathrm{pH}=7$, the relevant spectra are reported in Figure 4. Careful control of the $\mathrm{pH}$ was made necessary by the dependence of the absorption and emission spectral features of $\mathbf{1}$ on the acidity of the medium: at $\mathrm{pH}$ lower than 7 , important changes occur, clearly evidencing the protonation of the porphyrin ${ }^{84,85}$ (Figures S21, S22). 


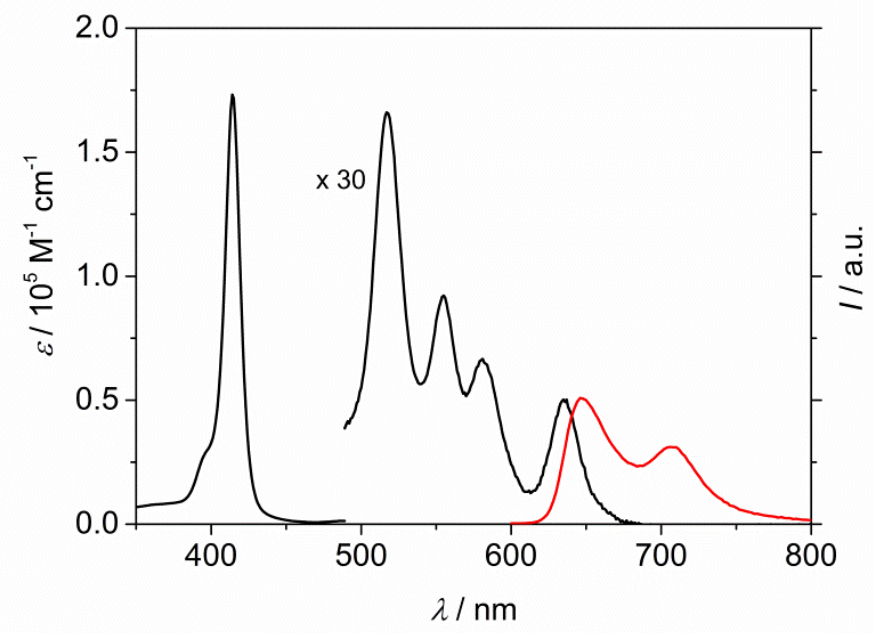

Figure 4. Absorption (black) and arbitrarily scaled corrected emission (red) spectra of $\mathbf{1}$ in water at $\mathrm{pH}=7$. The Q-band region $(490-700 \mathrm{~nm})$ is amplified by a factor 30 .

The measured fluorescence quantum yield of $\mathbf{1}$ in water is 0.14 and the lifetime in the same solvent is $8.5 \mathrm{~ns}$, comparable with those of other water soluble free-base porphyrins. ${ }^{8.87}$ These values are indicative of absence of aggregation phenomena in the range of concentration explored $(<5 \mu \mathrm{M})$ and show that the presence of the four appended Gd(III) complexes is not detrimental both to the absorption and to the fluorescence properties of the porphyrin.

The singlet oxygen production quantum yield of $\mathbf{1}$ was determined by an indirect method, using anthracene-9,10-dipropionic acid (ADPA) as a singlet oxygen trap with reference to 5,10,15,20-tetrakis (4-sulphonatophenyl)-porphyrin in water $\left(\mathrm{TPPS}_{4}, \phi_{\Delta}=0.51\right)^{64,65}$ (see Experimental Section and Figure S24 for details). The value of $\phi_{\Delta}=0.45$ has been obtained, similar to the one of the widely explored reference porphyrin $\mathrm{TPPS}_{4}$, indicating that compound 1 has a potential as effective photosensitizer in aqueous solution.

The latter experiment also evidenced that compound $\mathbf{1}$ is stable upon irradiation at $516 \mathrm{~nm}$ and in presence of singlet oxygen, as confirmed by the invariance of its absorption spectrum (see Figure S24 c). These characteristics are important in view of its in vivo application as a photosensitizer.

\section{In cell studies}

Cellular uptake and colocalization are important factors to evaluate the potential of the new conjugate as theranostic agent. Gd-based contrast agents are mostly extracellular and linking several Gd-complexes on a PDT photosensitizer will impact the cellular uptake, localization, toxicity, PDT activity and imaging ability of the conjugate. Increasing the number of Gd 
complexes on a porphyrin derivative core can prevent its cellular uptake as observed by Song et al..$^{5}$ in conjugates with four or eight $\mathrm{Gd}$ complexes or it can decrease its phototoxicity, as reported by Pandey and coworkers ${ }^{5 s}$ for the conjugate with six Gd complexes as compared to the one with four $\mathrm{Gd}$ complexes.

Internalization can be evidenced using classical confocal microscopy, taking advantage of the significant fluorescence quantum yield of $\mathbf{1}$. The cellular uptake of $\mathbf{1}$ in HeLa cells was slow, as already reported for other large molecular systems incorporating $\mathrm{Gd}$ complexes $^{55,57}$ and a stable fluorescence signal was detected after 24 hours incubation, while no signal was recorded after two hours incubation (See Figure S26). Compound 1 appears to accumulate in subcellular vesicles with a diffuse residual presence in the whole cell. Co-localization studies (Figure 5) that target nucleus, mitochondria and lysosomes showed that the vesicles involved are lysosomes (co-localization factor of 50\% with Lysotracker blue).

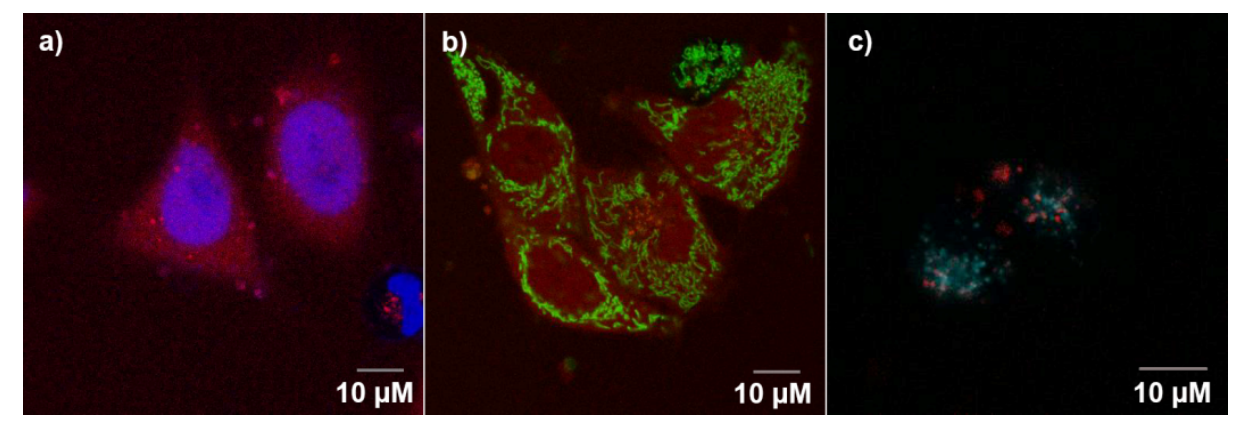

Figure 5. Co-localization studies of $\mathbf{1}(1 \mu \mathrm{M})$ after 24 hours incubation with a) Hoechst 33258 b) Mitotracker green c) Lysotracker blue in HeLa cells.

$\mathrm{T}_{1}$ maps of phantom at $7 \mathrm{~T}$ obtained from HeLa cell pellets gave further evidence of the cellular uptake of compound $\mathbf{1}$ and demonstrated its MR imaging capability (Figure 6 and Table S4). The concentration of Gd(III) per cell was determined with ICP-MS. Even with a low incubation concentration of $2.5 \mu \mathrm{mol}$ of $\mathbf{1}$ and at a high magnetic field (300 MHz), the sample of cells showed a lower T1 value than the one without Gd(III). The T1 value significantly decreased using an incubation concentration of $6 \mu \mathrm{mol}$. The linear relationship between $T_{1}$ and the amount of $\mathrm{Gd}(\mathrm{III})$ internalized is consistent with cellular incorporation of the tetranuclear $\mathrm{Gd}(\mathrm{III})$ conjugate 1 (Table S4). These results are therefore promising and demonstrate that this contrast agent comprising four $\mathrm{Gd}(\mathrm{III})$ complexes attached to a porphyrin core could be applied at considerably lower doses than what is typically used for clinical MR imaging $(100 \mu \mathrm{mol} / \mathrm{kg})$. 


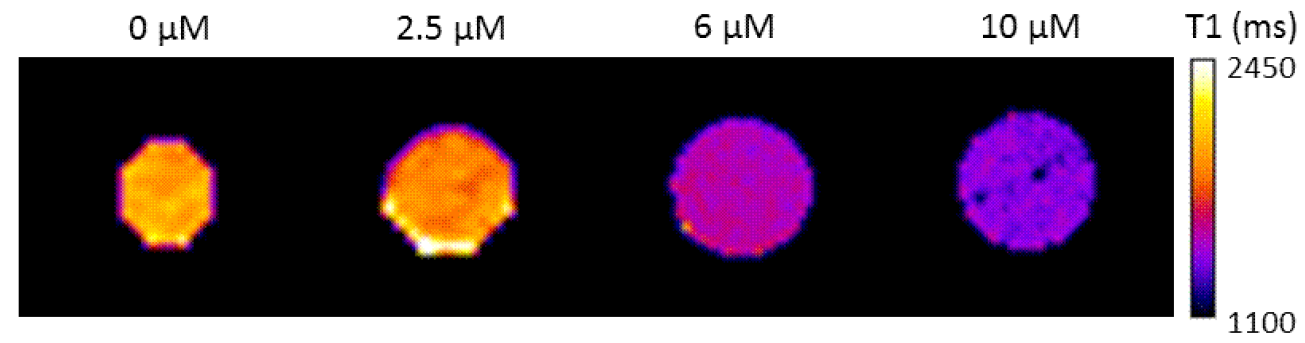

Figure 6. $\mathrm{T}_{1}$ maps of phantom at $7 \mathrm{~T}$ of HeLa cell pellets. Cells were incubated for 24 hours with different concentrations $(0-10 \mu \mathrm{mol})$ of compound $\mathbf{1}$.

The dark cytotoxicity of $\mathbf{1}$ was investigated by classical MTT assay after 24 hours incubation. A low cytotoxicity of $\mathbf{1}$ was assessed for concentrations below $5 \mu \mathrm{M}$ with cell viability $>90 \%$ (Figure 7). The concentration of 1 required to kill $50 \%$ of the cells $\left(\mathrm{IC}_{50}\right)$ was estimated to be about $50 \mu \mathrm{M}$. The $\mathrm{IC}_{50}$ value for the dark toxicity of $\mathbf{1}$ is closer to the range of the one reported for related free base porphyrins $(1-30 \mu \mathrm{M})^{88,89}$ than to that of gadolinium complexes used for MRI (in the range of 15-20 mM).

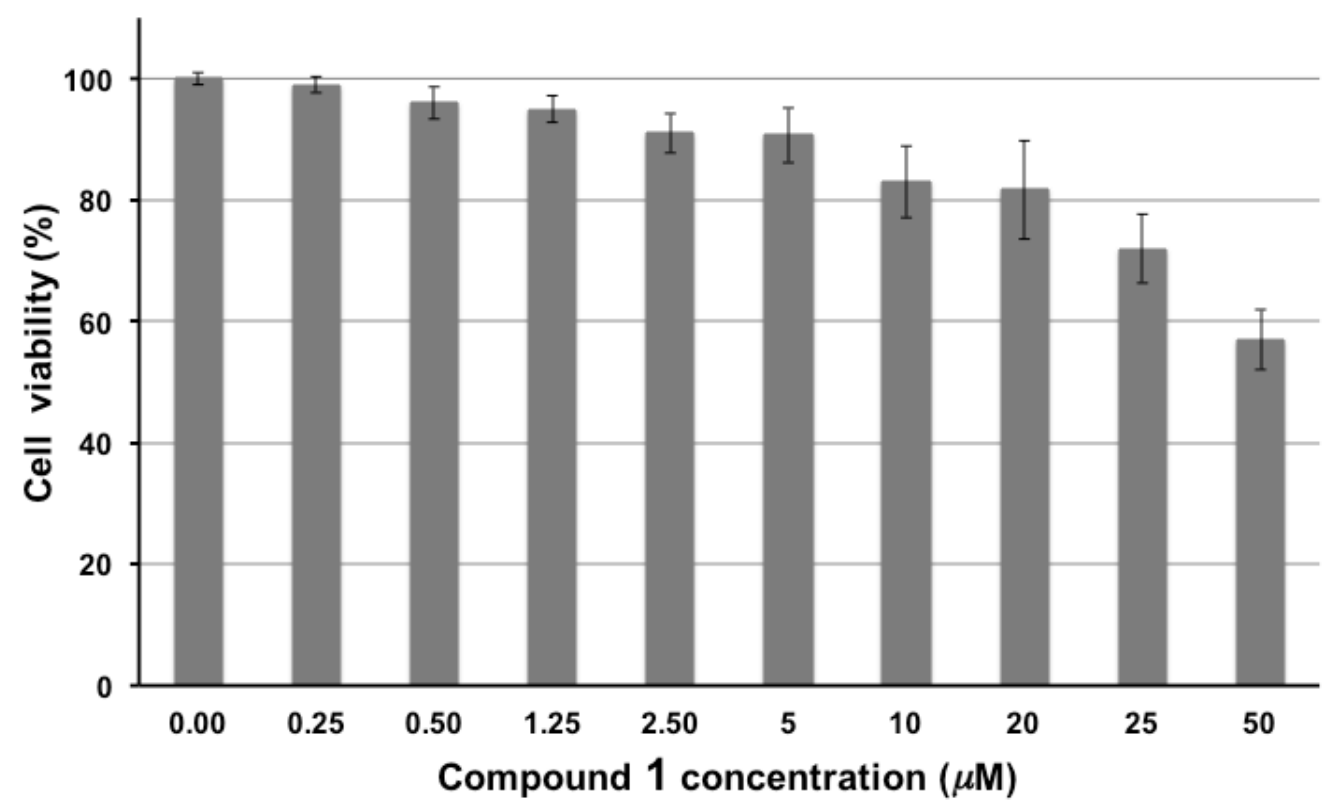

Figure 7. HeLa cells viability after 24 hours incubation at $37^{\circ} \mathrm{C}$ in the dark with various concentrations of $\mathbf{1}$.

The one-photon excited phototoxicity ability of $\mathbf{1}$ was assessed on HeLa cell culture incubated 24 hours with 1 at two concentrations $(2.5 \mu \mathrm{M}$ and $6 \mu \mathrm{M})$ and irradiated at $636 \mathrm{~nm}$ for one hour at various light intensities. The cell viability was determined 4 hours post irradiation by using a MTT test. The results are shown in Figure 8. 


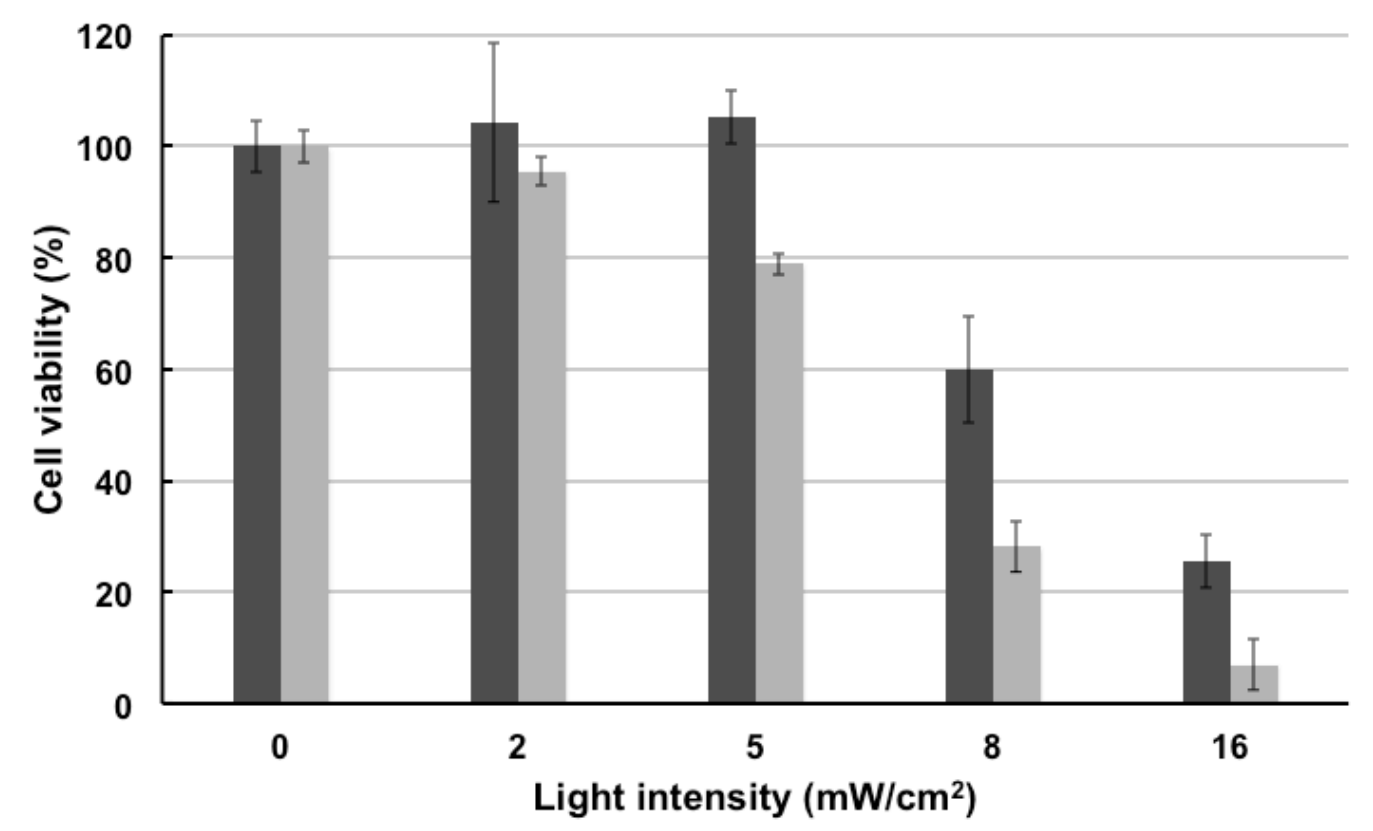

Figure 8. Phototoxicity of 1 evaluated from the HeLa cells viability following 1 hour irradiation at $636 \mathrm{~nm}$ at various light intensities after 24 hours incubation with $\mathbf{1}$ at $2.5 \mu \mathrm{M}$ (dark grey) and $6 \mu \mathrm{M}$ (light grey).

Irradiation with light intensity over $8 \mathrm{~mW} / \mathrm{cm}^{2}$ induces significant cell death, and the $50 \%$ cell death induction by light irradiation was estimated to be 32 and $21 \mathrm{~J} / \mathrm{cm}^{2}$ for a concentration of 1 of 2.5 and $6 \mu \mathrm{M}$ respectively.

The phototoxicity obtained in these PDT type experiments and the MR images observed in cells incubated with compound $\mathbf{1}$ demonstrate promising potential for this molecule as theranostic agent.

\section{Conclusion}

We have synthesized a bifunctional system consisting of four anionic [Gd(DTTA)] complexes for MR imaging linked to a porphyrin core, as photosensitizer for PDT. The conjugate displays remarkably high longitudinal relaxivity for a molecular system of medium size $\left(r_{1}=43.7 \mathrm{mmol}^{-1} . \mathrm{S}^{-1}\right.$ per Gd(III) center and $173.6 \mathrm{mmol}^{-1} \cdot \mathrm{s}^{-1}$ per molecule in water at 20 MHz and 298K). Furthermore, as shown from the $\mathrm{T}_{1}$-weighted phantom MRI experiments, the relaxivity per $\mathrm{Gd}(\mathrm{III})$ remains high at very high magnetic field, $8.68 \mathrm{mM}^{-1} . \mathrm{S}^{-1}$ at $7 \mathrm{~T}$ and $20^{\circ} \mathrm{C}$ as compared to $[\mathrm{Gd}(\mathrm{DTPA})]^{2 \cdot}\left(r_{1}=3.58 \mathrm{mM}^{-1} \cdot \mathrm{s}^{-1}\right)$. These features are assigned to (i) the design of a molecular system with restricted internal flexibility consisting of a large and rigid central planar core connected with short linkers to four Gd(III) complexes (ii) the presence of two 
inner-sphere water molecules for each Gd(III). The high density of relaxivity is particularly appealing for imaging at high magnetic fields and at low contrast agent doses. Moreover, the conjugate displays appropriate photophysical properties as a traceable photosensitizer for PDT, i.e. a remarkable fluorescence quantum yield of 0.14 and a high singlet oxygen production quantum yield of 0.45 in water. Both luminescence and MRI studies evidenced cellular internalization of the conjugate at low $\mu \mathrm{M}$ concentration. Phototoxicity measurements performed on Hela cells gave an appreciable $\mathrm{LD}_{50}$ value of $21 \mathrm{~J} / \mathrm{cm}^{2}$ at $6 \mu \mathrm{M}$ incubation concentration. These results demonstrate that both MR-imaging and photosensitization functionalities can be achieved with this molecular system, which makes this conjugate promising as theranostic agent. Further studies are planned to evaluate the efficiency of the compound in vivo.

\section{Supporting information available}

Experimental details and analytical data can be found in the Supporting Information.

\section{Acknowledgement}

The icFRC (http://wwwicfrc.fr), LabEx CSC and Region Alsace are gratefully acknowledged for a fellowship to JS and the Ministry of Education and Research for a $\mathrm{PhD}$ fellowship to SJ. Funding from the Italian CNR (Project PM.P04.010 "MACOL"), MIUR project PRIN 2010CX2TLM, MIUR-CNR project Nanomax N-CHEM and the French "Ligue contre le Cancer" are gratefully acknowledged. Blandine Guignard is thanked for her help during MRI exams. Dr. F. Manoli (ISOF-CNR) is acknowledged for a loan of ADPA and Dr. Lucia Flamigni (ISOF-CNR) is thanked for helpful discussion.

\section{References}

(1) E. Terreno, F. Uggeri, S. Aime, J. Control. Release, 2012, 161, 328-337.

(2) J. Kim, Y. Piao, T. Hyeon, Chem. Soc. Rev., 2009, 38, 372-390.

(3) J. Xie, S. Lee, X. Chen, Adv. Drug Deliv. Rev., 2010, 62, 1064-1079.

(4) X. Chen, S. S. Gambhir, J. Cheon, Acc. Chem. Res., 2011, 44, 841-841.

(5) R. Kopelman, Y.-E. Lee Koo, M. Philbert, B. A. Moffat, G. Ramachandra Reddy, P. McConville, D. E. Hall, T. L. Chenevert, M. S. Bhojani, S. M. Buck, A. Rehemtulla, B. D. Ross, J. Magn. Magn. Mater., 2005, 293, 404-410. 
(6) G. R. Reddy, M. S. Bhojani, P. McConville, J. Moody, B. A. Moffat, D. E. Hall, G. Kim, Y.-E. L. Koo, M. J. Woolliscroft, J. V. Sugai, T. D. Johnson, M. A. Philbert, R. Kopelman, A. Rehemtulla, B. D. Ross, Clin. Cancer Res., 2006, 12, 6677-6686.

(7) A. Vaidya, Y. Sun, Y. Feng, L. Emerson, E.-K. Jeong, Z.-R. Lu, Pharm. Res., 2008, $25,2002-2011$.

(8) W. T. Al-Jamal, K. Kostarelos, Acc. Chem. Res., 2011, 44, 1094-1104.

(9) T. Lammers, S. Aime, W. E. Hennink, G. Storm, F. Kiessling, Acc. Chem. Res., 2011, 44, 1029-1038.

(10) L. Y. Rizzo, B. Theek, G. Storm, F. Kiessling, T. Lammers, Curr. Opin. Biotechnol., 2013, 24, 1159-1166.

(11) M. Muthu, D. Leong, L. Mei, S. Feng, Theranostics, 2014, 4, 660-677.

(12) L. B. Josefsen, R. W. Boyle, Theranostics, 2012, 2, 916-966.

(13) M. H. Lee, J. L. Sessler, J. S. Kim, Acc. Chem. Res., 2015, 48, 2935-2946.

(14) R. Kumar, W. S. Shin, K. Sunwoo, W. Y. Kim, S. Koo, S. Bhuniya, J. S. Kim, Chem. Soc. Rev., 2015, 44, 6670-6683.

(15) P. Caravan, J. J. Ellison, T. J. McMurry, R. B. Lauffer, Chem. Rev., 1999, 99, 22932352 .

(16) P. Caravan, Chem. Soc. Rev., 2006, 35, 512-523.

(17) P. Hermann, J. Kotek, V. Kubicek, I. Lukes, Dalton Trans., 2008, 3027-3047.

(18) E. Terreno, D. D. Castelli, A. Viale, S. Aime, Chem. Rev., 2010, 110, 3019-3042.

(19) E. Tóth, L. Helm, A. E. Merbach, eds. J. Wiley and Sons, The Chemistry of Contrast Agents in Medical Magnetic Resonance Imaging, Relaxivity of Gadolinium(III) Complexes (Chapter 2) 2nd edn., 2013, pp. 25 - 82.

(20) V. M. Runge, T. Ai, D. Hao, X. Hu, Invest. Radiol., 2011, 46, 807-816.

(21) M. Botta, L. Tei, Eur. J. Inorg. Chem., 2012, 2012, 1945-1960.

(22) J. B. Livramento, É. Tóth, A. Sour, A. Borel, A. E. Merbach, R. Ruloff, Angew. Chem. Int. Ed., 2005, 44, 1504-1408.

(23) J. Costa, É. Tóth, L. Helm, A. E. Merbach, Inorg. Chem., 2005, 44, 4747-4755.

(24) J. B. Livramento, C. Weidensteiner, M. I. M. Prata, P. R. Allegrini, C. F. G. C. Geraldes, L. Helm, R. Kneuer, A. E. Merbach, A. C. Santos, P. Schmidt, É. Tóth, Contrast Media Mol. Imaging, 2006, 1, 30-39.

(25) J. B. Livramento, L. Helm, A. Sour, C. O'Neil, A. E. Merbach, E. Toth, Dalton Trans., 2008, 1195-1202. 
(26) L. Moriggi, A. Aebischer, C. Cannizzo, A. Sour, A. Borel, J.-C. G. Bunzli, L. Helm, Dalton Trans., 2009, 2088-2095.

(27) S. Aime, M. Botta, S. Geninatti Crich, G. B. Giovenzana, G. Jommi, R. Pagliarin, M. Sisti, Inorg. Chem., 1997, 36, 2992-3000.

(28) J. Xu, D. G. Churchill, M. Botta, K. N. Raymond, Inorg. Chem., 2004, 43, 5492-5494.

(29) A. Datta, K. N. Raymond, Acc. Chem. Res., 2009, 42, 938-947.

(30) S. Aime, L. Calabi, C. Cavallotti, E. Gianolio, G. B. Giovenzana, P. Losi, A. Maiocchi, G. Palmisano, M. Sisti, Inorg. Chem., 2004, 43, 7588-7590.

(31) B. Hofmann, A. Bogdanov, E. Marecos, W. Ebert, W. Semmler, R. Weissleder, J. Mag. Reson. Imaging, 1999, 9, 336-341.

(32) C. P. Gros, A. Eggenspiller, A. Nonat, J.-M. Barbe, F. Denat, Med. Chem. Commun., 2011, 2, 119-125.

(33) A. Eggenspiller, C. Michelin, N. Desbois, P. Richard, J.-M. Barbe, F. Denat, C. Licona, C. Gaiddon, A. Sayeh, P. Choquet, C. P. Gros, Eur. J. Org. Chem., 2013, 2013, 66296643.

(34) E. R. Trivedi, Z. Ma, E. A. Waters, K. W. Macrenaris, R. Subramanian, A. G. M. Barrett, T. J. Meade, B. M. Hoffman, Contrast Media Mol. Imaging, 2014, 9, 313-322.

(35) N. Desbois, C. Michelin, Y. Chang, V. Stupar, M. Bonnaud, S. Pacquelet, C. P. Gros, Tetrahedron Lett., 2015, 56, 7128-7131.

(36) B. C. Wilson, M. S. Patterson, Phys. Med. Biol., 2008, 53, R61-R109.

(37) M. Ethirajan, Y. Chen, P. Joshi, R. K. Pandey, Chem. Soc. Rev., 2011, 40, 340-362.

(38) A. E. O’Connor, W. M. Gallagher, A. T. Byrne, Photochem. Photobiol., 2009, 85, 1053-1074.

(39) E. S. Nyman, P. H. Hynninen, J. Photochem. Photobiol. B, 2004, 73, 1-28.

(40) A. B. Ormond, H. S. Freeman, Materials, 2013, 6, 817-840.

(41) M. Pawlicki, H. A. Collins, R. G. Denning, H. L. Anderson, Angew. Chem. Int. Ed., 2009, 48, 3244-3266.

(42) P. Couleaud, V. Morosini, C. Frochot, S. Richeter, L. Raehm, J.-O. Durand, Nanoscale, 2010, 2, 1083-1095.

(43) A. Kamkaew, S. H. Lim, H. B. Lee, L. V. Kiew, L. Y. Chung, K. Burgess, Chem. Soc. Rev., 2013, 42, 77-88.

(44) K. Ogawa, Y. Kobuke, Biomed. Res. Int., 2013, 2013, Article ID 125658, 125651125611 .

(45) S. S. Lucky, K. C. Soo, Y. Zhang, Chem. Rev., 2015, 115, 1990-2042. 
(46) S. Singh, A. Aggarwal, N. V. S. D. K. Bhupathiraju, G. Arianna, K. Tiwari, C. M. Drain, Chem. Rev., 2015, 115, 10261-10306.

(47) J. P. Celli, B. Q. Spring, I. Rizvi, C. L. Evans, K. S. Samkoe, S. Verma, B. W. Pogue, T. Hasan, Chem. Rev., 2010, 110, 2795-2838.

(48) S. S. Kelkar, T. M. Reineke, Bioconjugate Chem., 2011, 22, 1879-1903.

(49) C. Truillet, F. Lux, J. Moreau, M. Four, L. Sancey, S. Chevreux, G. Boeuf, P. Perriat, C. Frochot, R. Antoine, P. Dugourd, C. Portefaix, C. Hoeffel, M. Barberi-Heyob, C. Terryn, L. van Gulick, G. Lemercier, O. Tillement, Dalton Trans., 2013, 42, 12410-12420.

(50) X. Liang, X. Li, L. Jing, X. Yue, Z. Dai, Biomaterials, 2014, 35, 6379-6388.

(51) C.-T. Yang, P. Chandrasekharan, T. He, Z. Poh, A. Raju, K.-H. Chuang, E. G. Robins, Biomaterials, 2014, 35, 327-336.

(52) D. Bechet, F. Auger, P. Couleaud, E. Marty, L. Ravasi, N. Durieux, C. Bonnet, F. Plénat, C. Frochot, S. Mordon, O. Tillement, R. Vanderesse, F. Lux, P. Perriat, F. Guillemin, M. Barberi-Heyob, Nanomedicine: NBM, 2015, 11, 657-670.

(53) F. Hindré, M. L. Plouzennec, J. D. de Certaines, M. T. Foultier, T. Patrice, G. Simonneaux, J. Mag. Reson. Imaging, 1993, 3, 59-65.

(54) G. Li, A. Slansky, M. P. Dobhal, L. N. Goswami, A. Graham, Y. Chen, P. Kanter, R. A. Alberico, J. Spernyak, J. Morgan, R. Mazurchuk, A. Oseroff, Z. Grossman, R. K. Pandey, Bioconjugate Chem., 2005, 16, 32-42.

(55) L. N. Goswami, W. H. White, J. A. Spernyak, M. Ethirajan, Y. Chen, J. R. Missert, J. Morgan, R. Mazurchuk, R. K. Pandey, Bioconjugate Chem., 2010, 21, 816-827.

(56) J. A. Spernyak, W. H. White, M. Ethirajan, N. J. Patel, L. Goswami, Y. Chen, S. Turowski, J. R. Missert, C. Batt, R. Mazurchuk, R. K. Pandey, Bioconjugate Chem., 2010, 21, 828-835.

(57) D. Aydın Tekdaş, R. Garifullin, B. Şentürk, Y. Zorlu, U. Gundogdu, E. Atalar, A. B. Tekinay, A. A. Chernonosov, Y. Yerli, F. Dumoulin, M. O. Guler, V. Ahsen, A. G. Gürek, Photochem. Photobiol., 2014, 90, 1376-1386.

(58) J. Luo, L.-F. Chen, P. Hu, Z.-N. Chen, Inorg. Chem., 2014, 53, 4184-4191.

(59) Y. Song, H. Zong, E. R. Trivedi, B. J. Vesper, E. A. Waters, A. G. M. Barrett, J. A. Radosevich, B. M. Hoffman, T. J. Meade, Bioconjugate Chem., 2010, 21, 2267-2275.

(60) J. Schmitt, V. Heitz, A. Sour, F. Bolze, P. Kessler, L. Flamigni, B. Ventura, C. S. Bonnet , É. Tóth, Chem. Eur. J., 2016, 22, 2275-2786.

(61) H. E. Gottlieb, V. Kotlyar, A. Nudelman, J. Org. Chem., 1997, 62, 7512-7515.

(62) P. G. Seybold, M. Gouterman, J. Mol. Spectrosc., 1969, 31, 1-13. 
(63) M. Hoebeke, X. Damoiseau, Photochem. Photobiol. Sci., 2002, 1, 283-287.

(64) C. Tanielian, C. Wolff, M. Esch, J. Phys. Chem., 1996, 100, 6555-6560.

(65) R. W. Redmond, J. N. Gamlin, Photochem. Photobiol., 1999, 70, 391-475.

(66) O. F. Yerly in VISUALISEUR 2.3.5, Vol. Lausanne, Switzerland, 1999.

(67) E. Dahlstedt, H. A. Collins, M. Balaz, M. K. Kuimova, M. Khurana, B. C. Wilson, D. Phillips, H. L. Anderson, Org. Biomol. Chem., 2009, 7, 897-904.

(68) J. Costa, R. Ruloff, L. Burai, L. Helm, A. E. Merbach, J. Am. Chem. Soc., 2005, 127, 5147-5157.

(69) H. Jaccard, P. Miéville, C. Cannizzo, C. Mayer, L. Helm, J. Biol. Inorg. Chem., 2014, $19,145-159$.

(70) L. Moriggi, C. Cannizzo, C. Prestinari, F. Berrière, L. Helm, Inorg. Chem., 2008, 47, 8357-8366.

(71) L. Moriggi, C. Cannizzo, E. Dumas, C. R. Mayer, A. Ulianov, L. Helm, J. Am. Chem. Soc., 2009, 131, 10828-10829.

(72) J. M. Bryson, W.-J. Chu, J.-H. Lee, T. M. Reineke, Bioconjugate Chem., 2008, 19, 1505-1509.

(73) J. B. Livramento, A. Sour, A. Borel, A. E. Merbach, É. Tóth, Chem. Eur. J., 2006, 12, 989-1003.

(74) P. L. De Sousa, J. B. Livramento, L. Helm, A. E. Merbach, W. Même, B.-T. Doan, J.C. Beloeil, M. I. M. Prata, A. C. Santos, C. F. G. C. Geraldes, É. Tóth, Contrast Media Mol. Imaging, 2008, 3, 78-85.

(75) B. C. Bookser, T. C. Bruice, J. Am. Chem. Soc., 1991, 113, 4208-4218.

(76) J. Platzek, U. Niedballa, B. Raduechel, P. Mareski, H.-J. Weinmann, A. Muehler, B. Misselwitz, Patent WO9626182A1, 1996, 32.

(77) Z. Zhang, M. T. Greenfield, M. Spiller, T. J. McMurry, R. B. Lauffer, P. Caravan, Angew. Chem. Int. Ed., 2005, 44, 6766-6769.

(78) G. S. Loving, P. Caravan, Angew. Chem. Int. Ed., 2014, 53, 1140-1143.

(79) Z. Kotkova, L. Helm, J. Kotek, P. Hermann, I. Lukes, Dalton Trans., 2012, 41, 1350913519.

(80) É. Tóth, D. Pubanz, S. Vauthey, L. Helm, A. E. Merbach, Chem. Eur. J., 1996, 2, 1607-1615.

(81) R. F. Pasternack, P. R. Huber, P. Boyd, G. Engasser, L. Francesconi, E. Gibbs, P. Fasella, G. Cerio Venturo, L. d. Hinds, J. Am. Chem. Soc., 1972, 94, 4511-4517.

(82) É. Tóth, L. Helm, K. E. Kellar, A. E. Merbach, Chem. Eur. J., 1999, 5, 1202-1211. 
(83) K. W.-Y. Chan, W.-T. Wong, Coord. Chem. Rev., 2007, 251, 2428-2451.

(84) P. J. Gonçalves, L. D. Boni, N. M. B. Neto, J. J. Rodrigues Jr, S. C. Zílio, I. E. Borissevitch, Chem. Phys. Lett., 2005, 407, 236-241.

(85) G. Varchi, V. Benfenati, A. Pistone, M. Ballestri, G. Sotgiu, A. Guerrini, P. Dambruoso, A. Liscio, B. Ventura, Photochem. Photobiol. Sci., 2013, 12, 760-769.

(86) L. P. F. Aggarwal, M. S. Baptista, I. E. Borissevitch, J. Photochem. Photobiol. A, 2007, 186, 187-193.

(87) K. Kalyanasundaram, Photochemistry of polypyridine and porphyrin complexes, 1992, Academic Press Limited: London, p420.

(88) D. A. James, D. P. Arnold, P. G. Parsons, Photochem. Photobiol., 1994, 59, 441-447.

(89) E. Nyarko, T. Hara, D. J. Grab, A. Habib, Y. Kim, O. Nikolskaia, T. Fukuma, M. Tabata, Chem. Biol. Interact., 2004, 148, 19-25.

(90) W. Zhang, C. Lu, G. Zhao, J. Zhang, X. Fang, P. Wang, X. Fang, J. Xu, W. Yang, Z. Anorg. Allg. Chem., 2015, 641, 578-585.

(91) G. Zhao, C. Lu, H. Li, Y. Xiao, W. Zhang, X. Fang, P. Wang, X. Fang, J. Xu, W. Yang, Inorg. Chim. Acta, 2013, 406, 146-152. 


\section{For Table of Contents Only}

A molecular system consisting of four $\mathrm{Gd}(\mathrm{III})$ complexes linked to a mesotetraphenylporphyrin core was synthesized as a bifunctional agent for MRI and photodynamic therapy (PDT). The relaxivity per Gd center $\left(43.7 \mathrm{mmol}^{-1} \cdot \mathrm{S}^{-1}\right)$ is the highest reported for a $\mathrm{Gd}$ contrast agent of medium size with two inner-sphere water molecules. In vitro and in cell studies demonstrated the very good capability of the molecule to act as photosensitizer for PDT and its strong potential as theranostic agent.

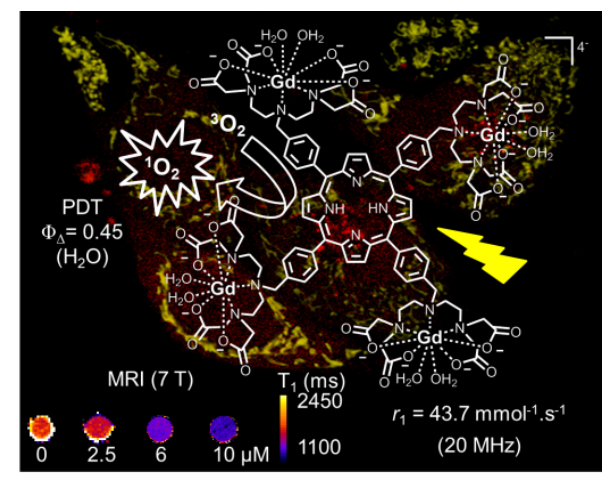

